

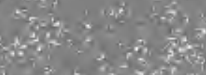

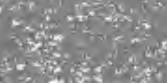

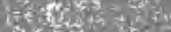

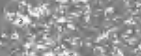

tosing

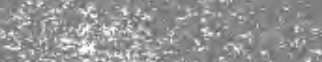

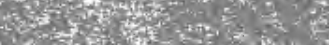

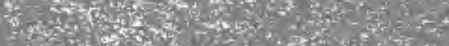



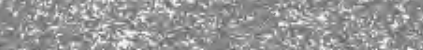



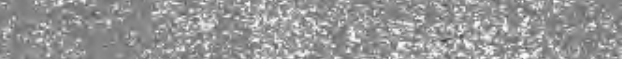

tistions

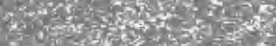

ingers?

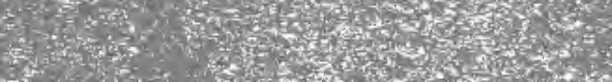





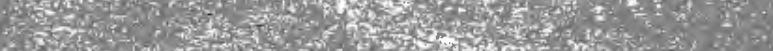

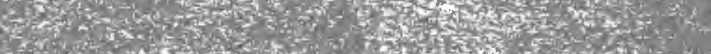

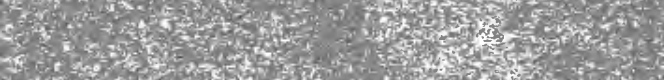

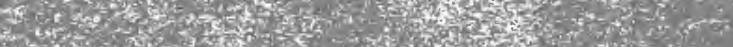

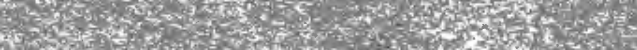

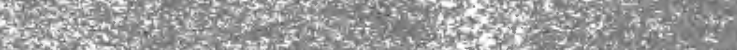

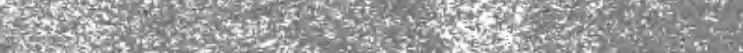

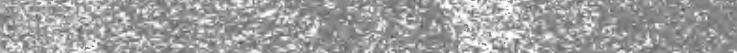

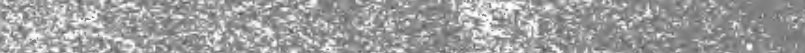

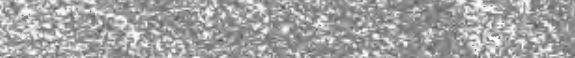

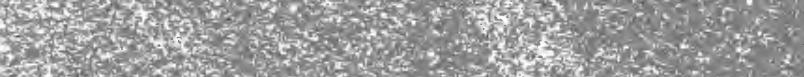

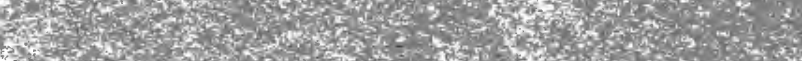

W.

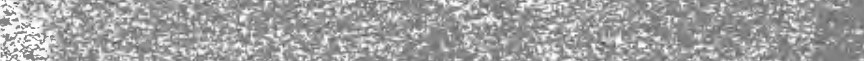

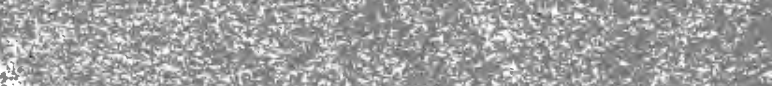

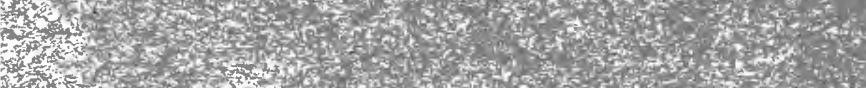

W.

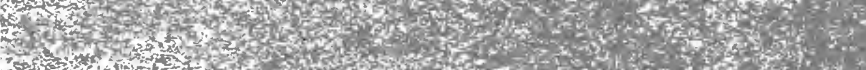

s.t.

T.

S.

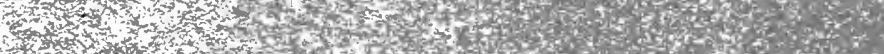

and 


\title{
AN EPIGRAPHIC COMMENTARY ON SUETONIUS'S LIFE OF GAIUS CALIGULA
}

\author{
$\mathrm{By}$ \\ RUsKin R. RosBorough
}

\begin{abstract}
A Thesis
Presented to the Faculty of the Graduate School in Partial Fulfillment of the Requirements for the Degree of Doctor of Philosophy
\end{abstract}

Philadelphia, Pennsylvania

1920 
Carissimis Parentibus 


\section{INTRODUCTION}

It has been my intention to present in this treatise the inscriptions which serve as a commentary on Suetonius's history of the reign of Caligula. Coming, as it clid, between the two comparatively long principates of Tiberius and Claudius, that of Caligula, covering a period of less than four years, is naturally not so fruitful in inscriptions. It is to be noted that Suetonius's account of Caligula's reign is confined virtually to the first twenty-one chapters, while the remaining twenty-nine chapters have to do with his career as a monster, which is a feature not likely to be dealt with in inscriptions. A few, at least, of the more prominent men in each reign survived their emperors, so that there is necessarily an overlapping in the accounts of Suetonius, and hence in the commentaries.

The Corpus Inscriptionum Latinarum has been searched in the preparation of this work and is the chief source used, while frequent reference has been made to the parallel collections of Greek inscriptions, especially the Inscriptiones Graecae ad Res Romanas Pertinentes, of which vols. I, III, and IV have been accessible. Where practicable, references to Dessau's Inscriptiones Latinae Selectae have been given on account of the general usefulness and accessibility of that work. Owing to war conditions, some numbers of the foreign periodicals have not been at my disposal. The following are the more important ones which have been used: Journal of Hellenic Studies, Bulletin de Correspondance Hellénique, Revue Archéologique, Notizie degli Scavi di Antichità, and Ephemeris Epigraphica. The Prosopographia Imperii Romani, Furneaux's Annals of Tacitus, Professor Rolfe's translation of Suetonius, and Foster's Dio have been invaluable aids; and special attention may be called to Dr. Holtzhausser's "Epigraphic Commentary on Suetonius's Life of Tiberius", Professor Walter Dennison's "Epigraphic Sources of the Writings of Gaius Suetonius Tranquillus", and Smilda's "Vita Divi Claudii". The following are the more important works on numismatics which I have consulted: Babelon's "Monnaies de la Republique Romaine", Cohen's "Description Historique des Monnaies"2", Eckhel's "Doctrina 
Numorum", and Head's publication of the Coins in the British Museum. The Teubner edition is the basis for the text.

It is hoped that this dissertation will prove to be of some value both from the epigraphie and from the historical point of view, and that it will help to demonstrate the value of epigraphy to the student of ancient history, which is constantly being corroborated, corrected, and supplemented by the discovery of inscriptions in various parts of the ancient world. Perhaps the most striking example of this to be found in this dissertation is the recently discovered fragment of the Fasti of Ostia, which gives us at least two facts hitherto unknown, viz: the date of Antonia's death, and the names of the two consuls who sueceeded Caligula and Claudius in $37 \mathrm{~A}$. D., besides throwing light on the eireumstances attending the funeral of Tiberius and the entry of Caligula into Rome. Although it has been my intention to make as complete a collection as possible of the inscriptions, there are undoubtedly some omissions.

I wish to express my appreciation and my thanks to the University of Pennsylvania for the award of a fellowship on the George Leib Harrison Foundation held by me during the years of 1917-1918 and 1919-1920.

Philadelphia, Pa., May 1, 1920. 


\section{AN EPIGRAPHIC COMMENTARY ON SUETONIUS'S LIFE OF GAIUS CALIGULA}

Germanicus, C. Caesaris pater: In none of the many Latin inscriptions of Germanicus have I found him alluded to as the father of Caligula, as Suetonius refers to him, although in a Greek inscription from Thera, I. Gr. XII. 3 suppl. $1392=$ Des-

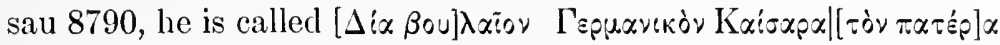

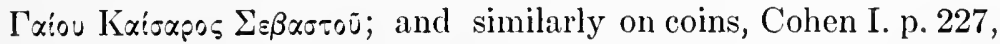
n. 18,21, p. 228, n. 3 . He was generally known by his adoptive name, Germanicus Caesar, and once as Germanicus Julius Caesar: CIL V. 6416, 3 from Ticinum: Germanico | Iulio [T]i. f., | Augusti nepot. | Divi pron. Caesari. Furneaux, Tac. Ann. Introd. i, p. 173, says that there is no record of his praenomen, or of any original cognomen, but I find an inscription from Eresus in Asia which indicates that he was perhaps called Germanicus Claudius (= Claudius Germanicus) prior to his adoption: IGR IV. 11:

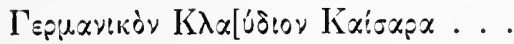

Drusi et minoris Antoniae filius: An inscription from Bilbilis, CIL II. $270^{*}$, scems to be the only one in Latin which mentions him as the son of Drusus, and hence, if it were genuine, would be dated prior to his adoption: germanico drusi f. sacr. c. huego qui in germania in leg. ii sub eo iii imp. . . . But we have one in Greek from Mytilene which mentions this relationship: IGR IV. $75=$ Ath. Mitteil. XIII. p. 63: 'O ōjuos $\mid \Delta$ poũzoy



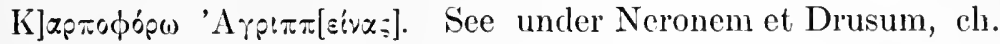
VII. A Greek inscription from Ilium, IGR IV. $206=$ Dessau

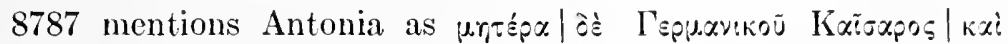

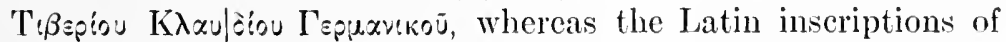
this type record the fact that she is the mother of the emperor Claudius, with no mention of Germanicus: e. g., CIL VI. 921: Antoniai | Augustai | Drusi | sacerdoti diमfi|Augusti | matri Ti. Claudi | Caisaris Aug. p. p., and CIL X. $1417=$ Dessau $150=$ Huebner 148: Antoniae Augustae matri Ti. Claudi । Caesaris Augusti Germanici . . . An inscription of interest 
in this connection is CIL IX. $3663=$ Dessau 149: Antonia Claudi Neronis [Drusi Germanici fratris Ti.] C[a]esaris [Aug.]. a Tiberio patruo adoptatus: On the adoption of Germanicus by Tiberius see Holtzhausser, p. 21, where there is a list of references to inscriptions containing various appellatives used after the adoption. Cf. also the following: CIL II. 4716, 6208, 6233; III. 14147; XII. 1848, 1849, in all of which Caligula is called the grandson of Tiberius; III. 12047; VI. $909=$ Dessau 176; X. 4572, 5050, 6649; XI. 1166; IGR IV. $75=$ I. Gr. XII. ii. 213, in which Nero, the son of Germanicus, is called the grandson of Tiberius; and coins, Cohen I. p. 224, n. 1, and p. 225, n. 2-6; and Eckhel VI. 210-211, coins from Greek colonies, on which Germanicus and Tiberius's son Drusus are called $\dot{\delta} \delta \varepsilon \lambda \phi o i$ and $\phi \imath \lambda \alpha \delta \hat{\delta} \lambda \phi \circ)$.

quaesturam quinquennio ante quam per leges liceret: CIL VI. $894=31194$ seems to be the only inscription which directly states that Germanicus held the quaestorship. before the legal age. It is very fragmentary, and has been restored as follows:

(a)



(b)

Dalmatos devicit reliquos e]orum in déditióne[m accepit cum qui]nquennium interces[sisset

missus est b]is qui pró consule G[allias et orientem obtineret ex senatus cons]ultó vóta per consules [

viri femi]naeque luxerunt. Hon[or

]alibus inferri solere [

i]psius et quando [

The inscription seems to refer to the events recorded by Dio, 56.17. See the note in the CIL. Henzen had assigned this inscription to Gaius Caesar, but he himself saw that line 1. in $b$ would not admit of such an interpretation. More recently, however, Mommsen has asserted that it refers to Germanicus, whom it seems to fit better. See Mommsen, Staatsr. I ${ }^{3}$, p. 
576, and Res Gestac Divi Augusti ${ }^{2}$ p. 54 sq. Germanicus's quaestorship in the years 7-12 A. D. is recorded in CIL III. 334 = Dessau 174 from Bithynia, an inscription dating from 11 A. D., when he was consul designatus; ef. also V. 4308 from Brixia in Cisalpine Gaul, dating from 18 A. D; and XIV. 3942 $=$ Dessau 173 from Nomentum in Latium. See also Dio 55.31. et post eam consulatum statim gessit: It is recorded in the Fasti Consulares of the year 765 a. u. c. that he held the consulship with Gaius Fonteius Capito as his colleague: CIL I ${ }^{2}$. p. 166. The Fasti Antiates have the same record: $I^{2}$. p. 72. An inscription from Cabeza del Griego, CIL. II. 3104, is further evidence of his consulship: Germanico / Caesari Ti. f., | Augusti n., | divi pro n., | cos., | L. Turellius | L. f. Geminus | aed. d.s.p. From the following inscriptions it will be seen that he had a different colleague after the first of July of that year: CIL VI. 765: Germanico Caesare | C. Visellio Varrone | cos.; 852: [dedicat.] est III non. [Aug. / Germanic]o Caesare / [C. Visellio] Varrone | [cos]; and 27526: [Ge]rmanico Caesare C. Visellio cos. I III k. Octobr. ossa condita |. . . . Cf. Dio 56. 17.

missusque ad exercitum in Germaniam . . . atque hoste mox devicto triumphavit: There is very little epigraphic eviclence of a direct nature for the German campaign of Germanicus. Several inscriptions bearing the names of slaves, and the small fragment from the arch of Tiberius perhaps refer to it; see Holtzhausser, p. 24. We have testimony to the success of his incursion into Germany in the many allusions to him as imperator II, both acclamations being attributable to the one campaign: CIL II. 1517, 2038, 2039, 2198, all from Baetica; VI. $909=$ Dessau $176,921=$ Dessau 222, both from Rome; IX. 962 from Vibinum, 2326 from Allifae; X. 460 from Buxentum, 513 from Salernum, 1415 = Dessau 177 from Herculaneum; and XI. 4776 from Spoletium, 6321 from Pisaurum. There are two probable sources of epigraphic evidence for Germanicus's triumph, one a fragment of the Fasti Amiternini for May 26, after 769 a.u.c.: CIL I², p. 243: [fer. s. ex c. quo]d eo die / [Germanicus C]aesar | [triumphans] invectus est | [in urbem]; and the other a coin, on the obverse of which Germanicus is pictured standing in a four-horse chariot (quadrigae) which is adorned with a Victory and a garland in relief, and holding a sceptre surmounted with an eagle; and on the reverse of which 
he is again represented in military attire holding a similar sceptre, along with the inscription: Signis recept. Germ. S. C. This coin was, in all probability, struck during his lifetime: Cohen I. p. 225, n. 7.

\section{$-\mathrm{I} .2-$}

Consul deinde iterum creatus: Many inscriptions refer to this consulship of $18 \mathrm{~A}$. D., which was shared with Tiberius, who was then consul for the third time: CIL I ${ }^{2}$ pp. 72, 73, Fasti Antiates et Lunenses for the year 771 a.u.c. $=18$ A. D.; II. $1517,2038,2039$, 2198, all from Baetica; IV. 1885 from the vicinity of Stabiae; V. 4308 from Brixia; VI. 921b. = Dessau 222, 909 = Dessau 176, 1985, 10051, 31205 all from Rome; IX. 962 from Vibinum, 2326 from Aeclanum; X. 460 from Buxentum, 513 from Salernum, 1415 from Herculaneum, 4572 from Caiatia, $6639=$ the Fasti Antiates cited above, cf. 6649 from Antium; XI. 3303 from Forum Clodi, 4776 from Spoletium, 6321 from Pisaurum; XIV. 2388 from Bovillae. From CIL XI. 3196 from Nepete in Etruria we learn that Germanicus had a second colleague in his second consulship also: Cereri August. | matri agr. | [4 lines omitted] | Germanico Caesare II | L. Seio Tuberone cos. | dies sacrifici XIII K. Mai. The Fasti Antiates, CIL I². p. 72, name Tubero as consul suffectus: Ti. Caesar August. III, Germanicus Caes. II, | [suf. K.] Feb. L. Seius Tubero; and CIL IX. 3664 from Marruvium has been restored by Mommsen as follows: Germanico Caesare [L. Seio Tuberone cos.].

ad componendum Orientis statum expulsus: There are many traces of Germanicus in inscriptions from the East, and there is a note of his own popularity as well as that of his family running through them: IGR III. 715 from Andriaca in Lycia:

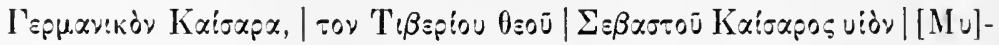

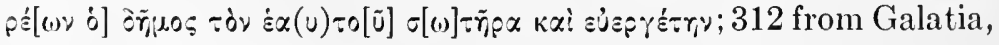
680, 716, from Lycia and Pamphylia, and 1056 IVa from Syria; IV. 11 from Eresus in Asia, 206, which is an inscription from Ilium, dedicated to his mother Antonia, when he approached Ilium in $18 \mathrm{~A}$. D. (Tac. Ann. II. 54); IV. 326, 327, 328, 330, 464, all from Pergamum, 723 from Eumenia, 979 from Samos, 1300 from near Cyme, dedicated to his son Nero and referring 


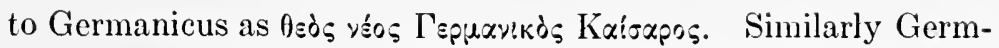

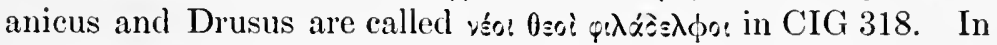
an inscription from Thera, I. Gr. XII. iii. $1392=$ Dessau 8790a, he is called " $[\Delta i \alpha$ Bou $] \lambda \alpha i o \nu$ ". If we may rely on epigraphic evidence, it is safe to say that few Romans, if any, were more beloved in the eastern provinces than was Germanicus. See ch. XIII for the decree of the Assians. The following inscription seems to show that it was by order of the emperor Tiberius that he was "expulsus" to the Orient: Bull. de.corr. hellén. vol. 26, p.161 = Dessau 8967: X vir stli. iudic. |q. Germanici $\mid$ Caesaris | leg. Ti. Caesaris Aug. | C. Iulius Christus | . . . . Christus is otherwise an unknown personage.

cum Armeniae regem devicisset: This reference is to Artaxias, the son of Palaemon king of Pontus, whom Germanicus proclaimed king of Armenia in 18 A. D. A coin of Germanicus, Cohen I. p. 225, n. 7, struck in Armenia in that year, has on the reverse a representation of Germanicus standing and placing a tiara upon the head of Artaxias, and the words: Germanicus. Artaxias.

Antiochiae obiit: From the Fasti Antiates (CIL I. p. 249) it appears that he died on October tenth. The Fasti Amiternini ( $\mathrm{I}^{2}$ p. 245) record ludi on that date, while the Ostian calendar of 19 A. D. has been restored, apparently on the basis of these records, to read: [Inferiae actae ob / e]xcessum G[ermanici]: CIL XIV. 244. The fragmentary inscription, CIL VI. $911=$ 31199 , appears to have contained important information regarding his career in the East, his death and cremation at Antioch, and the honours paid to him by decree of the senate. Cf. CIL VI. 31194 quoted above and Dio. 57. 18.

\section{$-\mathrm{II}-$}

obiit . . . ministerio et opera Cn. Pisonis, qui. . . Syriae praepositus: It is hardly to be expected that inscriptions would record such an act as this, but the absence of any inscriptions whatsoever from Syria and the eastern provinces which mention Piso is difficult to explain. Perhaps it is significant of his unpopularity, which is in striking contrast to the great popularity of his bitter enemy, Germanicus. Cf. Tił. 52, 3. Suetonius (Titus 4, 1 and Vesp. 1,2) considered it decidedly creditable 
to a man to have many inscriptions dedicated in his honour. Piso was consul with Tiberius in 747 a.u.c.: CIL ${ }^{2}$. p. 164, Fasti Cos. Cf. V. 8112, n. 83 from Cisalpine Gaul; VI. 7461 from Rome; IX. 5308 from Cupra Maritima in Regio V; X. 924 from Pompeii; and the tesserae consulares, CIL I. p. 747.

a senatu capitis damnatus est: Cf. Tac. Ann. II. 75-81; III. $8,10-16,17-18$. In spite of the fact that Tiberius refused to allow Piso's name to be erased from the fasti, there are a number of such erasures which must be attributed to his condemnation by the senate, e. g.: CIL VI. $385=$ Dessau $95 ; 2023$; and 7461 , from which, instead of Piso's name, the name of the municipium dedicating the inscription has been erased with a scalprum; thus they complied with the order of Tiberius, and at the same time obliterated the rcal significance of the inscription. There exist, however, inscriptions from which his name has not been erased: CIL V. 8112, n. 83; VI. 7461 from Rome; IX. 5308 from Cupra Maritima; and X. 924 from Pompeii.

formam et fortitudinem egregiam: There are several extant representations of Germanicus, of which the one from Gabij in the Louvre is generally considered the most authentic. The greater number of the busts and statues ascribed to him are of doubtful authenticity, while the coins which bear his image are, for the most part, posthumous or foreign. See J. J. Bernoulli, Römische Ikonographie II. 1. p. 232 sqq., and Cohen I. p. 225 sq. Cf. Dio 57. 18 .

\section{$-\mathrm{IV}-$}

Augustus . . . adoptandum Tiberio dederit: For this adoption see I. 1. His descent after adoption is given in a number of inscriptions, and I quote one which is representative: CIL II. 1517 from Baetica: [G]ermanico [C]aesari Ti. f. divi Aug. [n]epoti divi Iuli pro [n]epoti auguri, flam. [au]g., cos. iterum, [i]m[p.] iterum.

vulgo favorabilis: Particularly in the East Germanicus was universally beloved and popular with the masses, and traces of this are found in the inscriptions dedicated to him by $\delta \delta \bar{j} \mu \circ \varsigma$ 
in which such appellatives as these are applied to him: $\Delta$ ios Boudaios: I. Gr. XII. iii. $1393=$ Dessau 8790a from Thera,


Cf. IGR III. 680 from Patara; IV. 326, 327 from Pergamum. See the note on I.2, and the next paragraph.

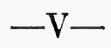

Tamen longe maiora et firmiora de eo iudicia in morte ac post mortem extiterunt: An inscription from Rome dedicated, without doubt, after his death is indicative of the esteem in which Germanicus was held: CIL VI. $909=$ Dessau 176: Pleps urbana quinque et | triginta tribuum | Germanico Caesari | Ti. Augusti f., | divi Augusti n., | auguri, flamini Augustali, | cos. iterum, imp. iterum, | aere conlato. Cf. also: CIL VI. 31274 from Rome (quoted under VII); X. 6638 (p. 665) and 6649 from Antium; XIV. 244 from Ostia. The decree of Assos (ch. XIII) is another tribute to the memory of Germanicus.

\section{-VII-}

Habuit in matrimonio Agrippinam, M. Agrippae et Iuliae filiam: Agrippina's epitaph best defines her relationship: CIL VI. $886=$ Dessau 180: Ossa | Agrippinae M. Agrippae [f.], | divi Aug. neptis, uxoris | Germanici Caesaris, | matris C. Caesaris Aug. I Germanici, principis. A number of inscriptions both Roman and Greek refer to her as the wife of Germanicus, e. g.: CIL V. 6359 from Laus in Cisalpine Gaul; VI. 31281, 32346, both from Rome; IX. 2201 from Telesia, 2635 from Aesernia; XI. 1167 from Veleia; IGR III. 94 from Sinope, 716 from Andriaca; IV. 980 from Samos; see coins: Cohen I. p. 231, n. 1-5; p. 232, n. 6-8. The firstof the se coins bears a portrait of a beautiful Roman woman, presumably Agrippina. See also Head: Cat. Brit. Mus., Lesbos: p. 204. Cf. Dio 57.5 and 59.1.

quorum duo infantes adhuc rapti, unus iam puerascens: These three children were born apparently between 8 and $11 \mathrm{~A}$. D. One of them was called Tiberius, another Gaius (cf. VII. 2); the name of the third is unknown, a fragment only of his epitaph having come down to us. The sepulchral inscriptions of all three of the little boys were found on the Via Flaminia near 
the Mausoleum of Augustus, in which they were doubtless buried: CIL VI. 888: Ti. Caesar | Germanici Caesaris f., | hic crematus est; VI. 889: C. Caesar | Germanici Caesaris f., | hic crematus est: VI. 890: . . [Caes]ar [Ge]rmanici Caesaris f., | hic crematus est. The three are given in Dessau 181.

ceteri. . . tres sexus feminini, Agrippina Drusilla Livilla totidem mares, Nero et Drusus et C. Caesar: An interesting inscription from Mytilene bears the names of all of these except Livilla: IGR IV. $7 \mathrm{~S}=$ I. Gr. XII. ii. $172=$ Dessau 8789:



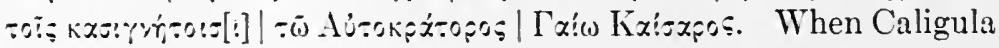
assumed the principate in $37 \mathrm{~A}$. D., both of his brothers were dead, Nero since 31 and Drusus since 33. Drusilla died in 38. (See Appendix.) It is worthy of note that Agrippina, who was then living, is here associated with her dead brothers and also with a sister who was probably dead at the time of the dedication of this inscription. A coin from Bithynia, Cohen I. p. 235 , is interesting in this connection, since it pictures the heads of Nero and Drusus on the obverse, and Agrippina, Drusilla and Julia (Livilla) in a standing posture on the reverse. Cf. also Cohen I. p. 237 , n. 4 , and p. 248 at the bottom of the page. The names of Germanicus and his sons Nero and Drusus are found on another interesting inscription, CIL VI. 31274, a marble fragment surviving from a monument which seems to have been dedicated "ob honorem Augustalitatis" by a municipium not far from Rome:
[G]ermanico
Neroni
Druso
Caesarj
Germanici
Germanici
Caesaris $f$.
Caesaris $\mathrm{f}$.
mus ob
hon.
August.
d. d.

On another tablet from this monument we might expect to find the names of Agrippina, Caligula, and Agrippina Minor, though such a one has not been found.

Agrippina: There are sereral inscriptions which tell something of her life, titles, and kinships: CIL II. 963 from Baetica: Iuliae Agrippinae [Neronis] | Caes. Aug. Germanici | matri Aug. n., | Civitas Aruccitana. Other interpretations of this inscription are given in CIL l. c. Huebner argues that the name of Nero was erased on purpose, because of his maltreatment of Agrippina. CIL VI. $921=$ Dessau 222: Iuliai Aug. $\mid$ Agrip- 
pínai | Germanici | Caisaris f., | Ti. Claudi Caisar. | Augustí | patris patriac; VI. $2041=$ Dessau 229, lines 16 and 32 , being the Acta Arvalium for the years 58-59 A. D.; VI. 8720, 8834, two inscriptions of officiales of the imperial family in which she is called simply Agrippina Germanici Caesaris f.; IX. 6362 from Trebula Mutesca, in which she is called Julia Agrippina; X. 6638, being the Fasti Antiates: I². p. 249: (Nov. 6) Ludi Agripp(ina) Iul(ia) nat(alis). Agrippina lived much at Antium, where she gave birth to Nero in the Domus Caesarum (CIL I². p. 335), and it is not surprising that her birthday should have been celebrated there with ludi. The Fasti Maffeiani (ibid. p. 226) and the Fasti Amiternini (p. 245) both record ludi on this day, though no mention is made of it as being her birthday. Cf. CLL X. $1574=$ Dessau 226 from Naples, an inscription from which her name has been erased. She is called the wife of the Emperor Claudius in CIL X. 933 from Pompeii, 1418 from Herculaneum; XI. $3600=$ Dessau $223=$ Huebner 102: Iúliae Augustáe | Germánici Caisaris [f.] Agrippínaí Ti. Cllaudi C]aisa[ris Augusti] | . . . ; Eph. Ep. VII. $1242=$ Dessau 220 from Nemus Dianae near Aricia, being also a titulus of Claudius, Nero, and Brittanicus: Pro [sa]lute Ti. [Claud]i Caesaris | [Aug. Gern] anici et Iuliae | [Agrippinae Aug. et T]i. Claudi Brittanici | [Caesaris et Neronis] Claudi Caesaris | !!!!!!!!!-us imp. Dia. lumen perp. Some inscriptions from the East are worthy of note in this connection: IGR IV. $81=$ I. Gr. XII. ii. 211 from

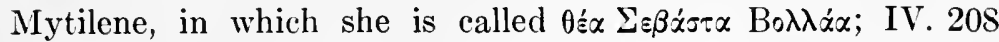
$=$ CIG 3610 from Ilium, addressed to Claudius and Agrippina and their children; IV. 560, 6 from Aezani, in which she and Nero are called $\delta \dot{v} \omega \theta \varepsilon \circ$; IV. 1052, a fragment from the island

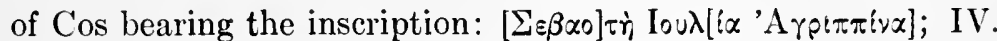
1062 from Cos, with a note explaining her relation to Rhea in that island. For coins bearing inscriptions and representations of Agrippina, see Eckhel VI. 257-259; Cohen I. p. 271, n. 1; p. 272 , n. 8 ; p. 275 , n. 1 ; p. $235-236$; p. 237 , n. 4 ; p. 248 , at bottom of page. Cf. Dio 60.31 sq.

Drusilla: There are many inscriptions from all parts of the Roman world dedicated to and mentioning the favourite sister of Caligula. One of these dates from her childhood: CIL VI. $5201=$ Dessau 1837: C. Papius Asclepiades | Papia Erotis I., | Iulia Iucunda nutrix | Drusi et Drusillac. She is usually ad- 
dressed as diva Drusilla, though in at least two inscriptions we find her called Julia Drusilla: CIL V. $5722=$ Dessau 194 from Ager Mediolanensis in Cisalpine Gaul, and XII. $1026=$ Dessau 195 from Avennio in Gallia Narbonensis. In VI. $8822=$ Dessau 1655 we find a dispensator of Claudius with the name of Cinnamus Drusillianus, which would indicate that he took his nomen from the name Drusilla. Cf. VI. 8823. Other inscriptions re. lating to Drusilla will be given under the several chapters where she is mentioned.

Livilla: She is called Julia by Tacitus (Ann. II. 54; VI. 15) and Dio $(60.8,27)$, and although all three of the sisters of Caligula were called Julia, she seems to be meant in CIL VI. 3998: Hymnus | paedagogus | [I]uliae Germanici | filiae, and again in VI. 10563: Acuto / Iuliae Germanici Caesar (sic) filiae ser. Cf. also CIL VI. 4352; IGR IV. 328, 464, and 476, from Pergamum, in which she is referred to as Ioudix véx Niкrpópos. A coin from Mytilene showing a bust of Livilla bears the in-

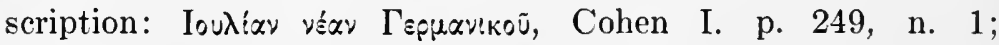
see also pp. 236, 237, and 248, where coins of all three sister's are given. The Greek inscriptions and coins may partly be accounted for by Tacitus's statement that she was born in Lesbos (see Ann. II. 54 and note). There is also epigraphic evidence for the name Livilla: CIL VI. $891=$ Dessau 188: Livilla [M. Vinici] | Germanici C[aesaris f.] | hic sita [est], being her sepulchral inscription and therefore to be dated after $\mathrm{Ca}$ ligula's death (ef. Suet. Cl. 29, Dio 60. 8, 27, and Seneca, Apoc. 10.). Mommsen has supplied her husband's name from Tac. Ann. VI. 15. She is probably referred to in CIL VI. $8711=$ Dessau 7803: Secunda | Livillaes | medica . . . . Cf. also XIV. 3661, and Eckhel VI. 219, 233.

Nero: Cf. Suet. Tib. LIV, and Holtzhausser p. 41 sqq. Considerable light is thrown on the short life of Nero by inscriptions. He is called Nero Caesar in CIL III. 2808 from Scardona in Dalmatia; V. 23 from Pola in Cisalpine Gaul, 4374 from Brixia; VI. 887, $914=$ Dessau 184, and 31274, all from Rome; X. 5393 from Aquinum, 6101 from Formiae; XI. 3336 from Blera, 3789 from Veii; XIV. 3017, a fragment from Praeneste. His name appears in the Ostian calendar, XIV. 244, lines 8-9, as simply Nero: VII Idus Iun. Nero to[gam virilem] | sumpsit. Cong. di[visit]. His full name, Nero Iulius Caesar, appears in 
IGR IV. $1300=$ CIG 3528 from near Cyme in Asia; CIL V. $6416=$ Dessau 107 from Ticinum, and perhaps in the very fragmentary inscription, V. 853 from Aquileia. His official titles were: flamen Augustalis: CIL III. 3808; VI. 887, 913; X. 798; XI. 3336; quaestor: VI. 887, 913; X. 798; XI. 3336; XIV 2965; sodalis Augustalis: VI. 913; X. 798; XI. 3336; duovir quinquennalis of Praeneste: XIV. 2965; sodalis Titius: VI. 913; frater Arvalis: VI. 913; fetialis: VI. 913. Inasmuch as all of these except "II vir quinquennalis" are recorded in VI.913, I give it in full: Neroni Caesari / Germanici Caesaris f., | Ti. Caesaris Augusti n., | divi Augusti pro n., | fláminî Augustáli, | sodáli Augustáli, | sodáli Titio, frátri Arváli, | fétiáli, quaestori | ex s. c. This inscription was dedicated between the years 27 , in which, according to Tacitus (Ann. III. 29), he held the quaestorship, and 29, the year of his condemnation before the senate (cf. Tac. Ann. V. 3, and see below in this chapter). I note that Tacitus in the passage referred to above (III. 29) says that the pontificate was decreed to Nero in the year 20 , but I find no evidence in inscriptions to support the statement, and I think it would have surely been included in the detailed inscription quoted above, VI. 913. It may be that Tacitus has confused him with his brother Drusus, who was pontiff and who was very closely associated with him in public life. Suetonius (ch. XII) implies that Drusus was augur also, but this is undoubtedly an error. See the note on XII. Further evidence regarding his official position is gained from three inscriptions of his prefects: CIL. V. 4374; X. 6101; and XIV. 3017. Cf. X. 5393. Suetonius does not tell us anything of Nero's love affairs, but from the following inscription we learn that he was betrothed: CIL VI. $914=$ Dessau 184: Iunia Silani [f., . . . spon] sa $\mid$ Neronis Caes[aris]. Literary evidence shows that he was married to Julia, the daughter of Drusus and Livilla (Claudius's sister): Tac. Ann. III. 29, IV. 68, VI. 27, and Dio 60. 18. Julia was betrothed to Sejanus and married to Rubellius Blandus after Nero was exiled. The following titulus from Rome concerns her: CIL VI. 4119: Elate Iuliae | Drusi Caesaris | filiae libertae | Aphrodisius C. Caesaris | ser. fec.

Drusus: The variations of his name are similar to those of his brother Nero referred to above: he is called Drusus Caesar in CIL II. 609; III. $380=$ Dessau 185; V. $4953=$ Dessau 187 
7567; X. 6101; XI. 3788; Dessau 186; IGR IV. $75=$ I. Gr. XII. ii. 213; Drusus Iulius: CIL II. 1553; Drusus: CIL VI. 31274, $5201=$ Dessau 1837, which is one relating to his childhood (see under Drusilla, above); and the full name, Drusus Iulius Germanicus, appears in CIL V. 6416 n. $9=$ Dessau 107 n. 9. It is noteworthy that the name Iulius, which was usually omitted in the house of Augustus, recurs here not among sons but among grandsons and great-grandsons. Cf. Mommsen, Staatsr. II ${ }^{2}$. p. 742 , note 2 . I have already called attention to the fact that the three sisters were called Iulia. See the note on Livilla above.

Drusus did not hold nearly as many offices as his brother Nero, the following being the only ones I find mentioned in inscriptions: praefectus urbi and sodalis Augustalis: Dessau 186 from Burdigalae; pontifex: CIL III. 380; duovir quinquennalis at Praeneste: XIV. 2965; cf. XIV. 3017. A Publius Vergilius is alluded to as praefect of Drusus: CIL V. 7567, and Publius Plautius Pulcher as "comes Drusi" in XIV. 3607. See the notes on Nero and on Ch. XII. Tacitus (Ann. VI. 40. 4) tells us that Drusus was married to Aemilia Lepida, to whom CIL VI. 9449 secms to refer, though Orelli 639 wrongly interprets it to mean Lepida the great-grand-daughter of Pompey the Great and Sulla the Dictator: Pudens M. Lepidi l. grammaticus. | Procurator eram Lepidae moresque regebam: | dum vixi, mansit Caesaris illa nurus. . . . Cf. Tac. Ann. III. 22, and Furneaux's note.

Neronem et Drusum senatus Tiberio criminante hostes iudicavit: There seems to be no direct epigraphic evidence for this statement, but several incidental facts seem worthy of mention here: this allusion, as in Tib. LIV, implies that accusation and judgment were brought against the two brothers together, and this is indicative of the close relationship existing between them, which is attested by the following inscriptions in which they are mentioned conjointly: CIL X. 6101: L. Arrio Salano | . . . | praef. quinq. Neronis et Drus[i] | Caesarum . . . ; XIV. 2965, 3017; and four coins described in Cohen I: (i) p. 234: Nero et Drusus Caesares, with a representation of the two in tunic and girdle and galloping on horseback, being a coin of Caligula struck in 37 A. D.; (ii) p. 234 n. 2.: a coin of Tiberius from Caesaraugusta in Spain: Nero Caesar, Drusus Caesar II 
vir. C(olonia) C(aesar) A(ugusta); (iii) p. 235: a coin of Tiberius from Nova Carthago: Nero et Drusus Caesares quinq. C(olonia) $\mathrm{V}$ (ictrix) I(ulia) C(arthago), with busts of the boys facing each other; (iv) p. 235-236 from Apamea in Bithynia: Drusus Nero Caesares d.d. and busts as in iii. There are at least two instances of separate inscriptions to them engraved on the same stone: CIL VI. 31274, quoted in full above in this chapter; IGR IV. 75 = I. Gr. XII. ii. 213 from Mytilene: (a) ['O ¿̇̃uos]

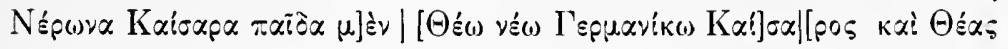

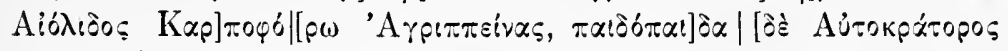

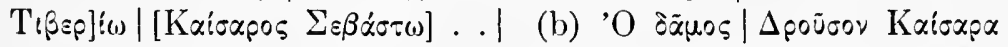

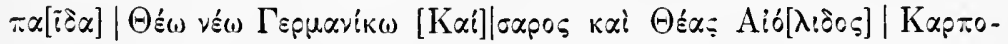

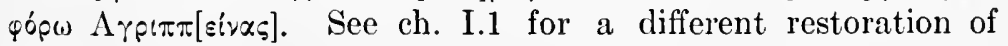
this inscription. Cf. also IGR IV. 78 from Mytilene One is reminded of the somewhat parallel relationship of Gaius and Lucius, the grandsons of Augustus. The absence of the name of Tiberius in inscriptions giving their descent may not in every case be a silent allusion to the treatment which they received at his hands. We could hardly expect Tiberius to be mentioned in their sepulchral inscriptions, of which the one of Nero has come down to us: Ossa | Neronis Caesaris / Germanici Caesaris f., | divi Aug. pron., flamin. | Augustalis, quaestoris: CIL. VI. 887. Similar omissions of Tiberius's name occur in CIL V. 6416 = Dessau 107 from Ticinum: Neroni Iulio | Germanici [f.,] | Aug. pronepot. | Caesari; II. 609 from Metellinum in Lusitania: Druso Caesari / Germanici / Caesaris f., / clivi Augusti | pronepoti patron[o]; V. 6416,9 = Dessau 107 from Ticinum: Druso Iulio / Germanici f., | Aug. pronepot. | Germanico. If the inscription CIL IX. $4209=$ Dessau 163 refers to them, it was certainly dedicated prior to their condemnation; but it seems rather to refer to Caligula and Tiberius Gemellus. See the note on XIV. 1 .

\section{-VIII. 1-}

C. Caesar natus pridie Kal. Sept.: This date for his birth is supported by the Fasti Vallenses, CIL I ${ }^{2}$, p. $240=$ VI. 2298: [Aug.] XXXI Nat. C. Caaesris (sic) Germanici; and also by the Fasti Pighiani, I². p. $246=$ VI. 2300: Nat. Germanic.

patre suo et $C$. Fonteio Capitone coss.: The consulship of Germanicus and Capito is recorded in the Fasti Consulares for the 
year 765 a.u.c.: CIL I². p. 166: Germanicus Ca[esar T]i. f., Augusti n., | C. Fonteius C. f., C. n., Capito; and again in the Fasti Antiates for the same year: I². p. 72. Cf. also V. 5607, which probably refers to the same Capito.

$C n$. Lentulus Gaetulicus: His name appears in the fasti of the Arval Brothers for the years 776 and 779 a.u.c., where he is mentioned as consul with C. Calvisius Sabinus for the latter year: CIL I2 ${ }^{2}$ p. 71 . Several other inscriptions go to prove that he was consul with the same colleague in 779 a.u.c., e. g.: CIL II. 2093 from Baetica: (six lines omitted) . . . posita k. Mart. | Cn. Cornelio Gaetulico, | C. Calvisio Sabino cos; III. 7153 = Ephem. Ep. V. 1463; VI. 343 from Rome; X. 896 from Pompeii; and XI. 3805 from Veii. $\mathrm{He}$ is mentioned as the father of Cornelia Caesia in VI. 1391. Cf. VI. $1392=$ Dessau 958, 9834, and 17170. In the Acta Arvalium of 39 A. D. his name is mentioned in connection with a conspiracy against Caligula: CIL VI. 32346: a. d. VI k. Novemb. | ob detecta nefaria con[silia in C. Germanic]um Cn. Lentuli Gae[tulici] . . . ; cf. Suet. Claud. 9; Dio 59. 22; Seneca, Ep. 4.7; Josephus, Ant. 19.1.3.

in Treveris vico Ambitarvio supra Confluentes; . . . aras - inscriptas ob Agrippinae puerperium: None of these inscriptions has been found. Tacitus, Ann. XII. 27. 1, says that Agrippina, Caligula's sister, was born in a town of the Ubii. This town, which was the capitol of the Ubii, is mentioned frequently in inscriptions, under the name of (1) Ara Agrippinensis: CIL III. 4479; XIII. 1836; (2) C(olonia) C(laudia) A(ra) A(grippinensis): XIII. 10015 nos. 108 and 115; XIII. 7827, 8255, 8335; (3) Claudia Ara: CIL III. 4465, 4475; VI. 3298, 3299, 3311, 31139; VIII. 2785, 3099. The colonists are called Agrippinenses in CIL II. 484; III. 10508, 10548, 14214; V. 6888; XII 674; XIII. 1844, 9698; and many others. In the time of Severus Alexander the city was called Colonia Claudia Augusta Agrippinensium: CIL IX. 1584, thus perpetuating the memory of Agrippina's residence in Germany with Germanicus.

\section{-VIII. 2-}

ex urbe Herculi sacra: That Hercules was worshipped as the patron god of Tibur is abundantly confirmed by epigraphic 
evidence. Several surnames of the god are also preserved in inscriptions from Tibur. CIL I. 1113: Herculei | C. Antestius Cn. f., | decuma facta iterum | dat; XIV. 3542: Herculi Domestico; 3543: Herculi Saxano (see Dessau's note in the Corpus); 3544: H(erculi) V(ictori) v(otum) s(olvit) | C. Iulius C. f., | Pal. Rufus | trib. militum bis, | fani curator | v(iator) q(uaestorius) $\mid$ ab aerario Saturni; 3545 and 3548: Herculi Invicto; 3546, 3547, 3549, 3550, 3551, and 3555: Herculi Victori; 3552: Herculi Tiburtino; 3553: Herculi Victori Certencino, being a cognomen derived from a place now unknown; 3554: Hercul[i] Tiburt. Vict. | et ceteris dis; 3599, 3600, 3601, 3609, 3650, 3673, $3674,3689,4242,4244,4258$, all mentioning men who were curatores fani Herculis Victoris, and 4257 of an aedituus $\mathrm{H}$ [erculis Victoris]. There is even one inscription from Rome to Hercules Tiburtinus: CIL VI. 30742, which probably marked a statio of the people of Tibur, such as the municipes had near the forum: cf. Suet. Nero XXXVII, and Pliny, N. H. 16. 236.

\section{$-\mathrm{IX}-$}

Caligulae cognomen castrensi ioco traxit: There seems to be no trustworthy epigraphic evidence for the surname Caligula. There is, however, a forged inscription purporting to come from Gallipoli near Constantinople, on which his name reads as follows: C. Caligula imp., August. p. p., p. max.: CIL III. 28.* See Appendix II. His name appears in a number of forms on the monuments: C. Caesar Germanicus, which Egbert (Latin Inscriptions, p. 126) gives as his usual designation, but which, according to the inscriptions, appears to be rather his name prior to his accessoin: CIL I2. p. $240=$ VI. 2298; II. $172=$ Dessau 190, $4716=$ Dessau 193, 6208; VI. 4331; XII. 1848, 1849 (the last two certainly dating prior to his principate). Gaius: CIL V. $5050=$ Dessau 206. Germanicus: CIL I². p. 246 = VI. 2300. C. Caesar: CIL V. 6641,8110 n. 18; VI. 1252 = Dessau 205, 4357, 27135; X. 902; XII. 256; and Notizie XIV (1917), p. 182. C. Caesar Augustus: CIL II. 4962 n. 4; IV. 669; VI. 8823, 31765; XIII. 1189; Bull. Comun. 1902, p. 213. Imp. C. Caesar: III. 6664, though this may not refer to Caligula, since he did not use the praenomen Imperator. Caesar Augustus: CIL VI. 811 = Dessau 192. C. Caesar Germanicus 
Augustus: CIL XII. 342. Finally, we come to what is undoubtedly his official imperial title: C. Caesar Augustus Germanicus: CIL I ${ }^{2}$. p. $247=$ X. 6638, 7; II. 6233, 6234; III. 2882, 2976, $8472=$ Dessau 5948, $9832=$ Dessau 5949, 9864a= Dessau 5950, $14147^{1}=$ Dessau 8899; V. $6641=$ Dessau 191; VI. $886=$ Dessau 180, 2028 (passim) $=$ Dessau 5032, $2029=$ 32346, 2030, 5188 = Dessau 1589; X. 796; XII. 2331; XIV. 2854; XV. 7816; and Notizie degli Scavi 1910, p. 68 . His Greek titles are for the most part translations of the Latin ones, though

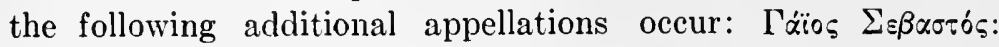

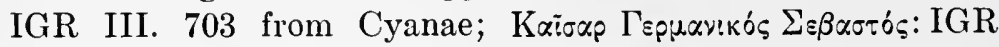

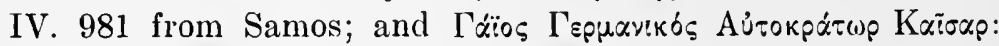
IGR IV. 1379. The inscriptions on coins are in general the same as those quoted above, and confirm the statement that $\mathrm{C}$. Caesar Augustus Germanicus was his imperial title. In addition to appellatives already cited, the following is found on coins: Caesar Augustus Germanicus: Cohen I. p. 236, n. 1, and p. 241, n. 30. (Cf. IGR IV. 981, above.) See Dio 57.5 and 59.1. et in furorem usque praecipites solus haud dubie ex conspectu suo flexit: It is tempting to see an allusion to this on a coin of Caligula, which represents him standing beside a curule chair upon a platform and haranguing five soldiers; it bears the inscription: Adlocut. coh.: Cohen I. p. 236, n. 1. Since, however, this coin dates from his principate, it is more reasonable to suppose that it refers to an incident of his German campaign. See the note on XLIII.

comitatus est patrem et Syriaca expeditione: I find no inscriptions from Syria mentioning Caligula and Germanicus, though several from Asia and the Asiatic provinces may be attributed to their having been in the East: IGR III. 703 from Cyanae in Lycia; IV. 76, 77, 78, from Mytilene; 145, 146 from Cyzicus; 945 from Chios; 981 from Samos; 1022 from Calymna; 1379 from Koula; and the coins given in Cohen I. p. 248 . It is definitely stated in the decree of Assos (ch. XIII) that Germanicus and Caligula had been in charge of the government of that city.

togam sumpsit . . . sine ullo honore qualis contigerat tirocinio fratrum eius: There is no mention in the various calendars of 
Caligula's assuming the toga virilis, which goes to prove the truth of Suetonius's statement. Furthermore, the following excerpt from the Ostian calendar indicates that some ceremony attended his brother Nero's assumption of the toga virilis: VII Idus Iun. Nero to[gam virilem] | sumpsit. Cong(iarium) di[visit]: CIL XIV. 244, lines 8-9.

\section{-XII.1-}

Iuniam Claudillam $M$. Silani nobilissimi viri $f(i l i a m)$ duxit uxorem: There seem to be no inscriptions mentioning her, but her father is named as consul suffectus for 768 a. u. c. in the Fasti Antiates: CIL X. 6639, line 12. He is mentioned also in a number of other inscriptions: CIL I. 762, 763, and XI. 6689 n. 119, (three tesserae), as consul for the year 768 with Drusus, the son of Tiberius; VI. 2028-c 35, as an Arval Brother; IV. 5214, a cursive inscription from a Pompeian wall, also naming him as consul with Drusus; XIV. 2466 and 2467 from Castrimoenium in Latium, mentioning his freedman M. Iunius Monimus; XIV. 3471. Three of the inscriptions relating to his consulship are dated and show that he was consul for the latter half of the year at least: CIL I. 762: Id. Aug.; I. 763: K. Dec; and the cursive one from Pompeii, IV. 5214: VIII Idus Nov.

Deinde augur in locum fratris sui Drusi destinatus: So far as Drusus is concerned, this seems to be an error on the part of Suetonius; for if Drusus had been augur, there would probably be some mention of the fact in inscriptions naming his offices: See the note on Drusus, ch. VII. Drusus, the son of Tiberius, however, was augur, but it seems improbable that any confusion in Suetonius's mind could result from this, inasmuch as this Drusus died when Caligula was a child of fifteen.

priusquam inauguraretur: The absence of evidence from inscriptions that Caligula was augur is in accord with Suetonius's implication that he was not actually installed in office.

ad pontificatum traductus est: Two inscriptions from Vienna in Gallia Narbonensis dedicated in Tiberius's lifetime may be cited in support of this: CIL XII. 1848: C. Caesari | Germanici f., | [Ti.] Augusti n., | divi Aug. pron., | Germanico | pontifici, q. | ; and XII. 1849: C. Caesari | Germanici f., | 'Ti. Aug. n., | [D]ivi Augusti | pronepoti, / Germanico | pontifici, q. |. As- 
suming that Dio (58.23) is correct in his statement that Caligula was made quaestor in $33 \mathrm{~A}$. D., we may date these inscriptions approximately, i. e. between 33 and 37 , the beginning of his principate.

Seiano . . . suspecto mox et oppresso: A similar expression in regard to Sejanus occurs in Tib. LXV, on which see Holtzhausser, p. 45. A rather obscure and fragmentary inscription from Rome seems to allude to some definite act of treason on the part of Sejanus: CIL VI. 10213. In the fasti of Nola for the year 31 the name of Tiberius in his fifth consulship stands alone, that of Sejanus having been erased, probably by order of Tiberius: CIL X. 1233 . Cf. X. 898 from Pompeii, from which Sejanus's name seems to have been erased and the space reinscribed. Other inscriptions relating to Sejanus are: CIL III. $12036=$ Eph. Epigr. VII. p. 424; VI. 6030, 10769; and XI. $4170=$ Dessau 157, which compliments Tiberius on his foresight in getting rid of Sejanus, who is called hostis perniciosissimus. Cf. Dio 57. 20 and 58. 4-9.

\section{$-\mathrm{XII} .3-$}

ad ulciscendam necem . . . fratrum: See the notes on Agrippina, Nero and Drusus, ch. VII.

\section{$-\mathrm{XIII}-$}

exoptatissimus princeps maximae parti provincialium ac militum . . . ob memoriam Germanici: That Caligula was popular with the provincials and soldiers because of their love for Germanicus is attested by a number of inscriptions from the provinces, many of which mention him as the son of Germanicus: CIL XII. 1848 and 1849 from Vienna, which are quoted in full under ch. XII; XII 256, 342, 651, 666, 3052, all from Gallia Narbonensis; XIII. 1189 from Aquitania; XIV. 2854 from Praeneste; and three from Pompeii, from two of which it appears that the people of Pompeii had conferred the duumvirate on him in 34 A. D.: CIL X. 901, 902, and from the third that they had conferred the quinquennalitas on him: X. 904. CIL III. $14147^{1}$ attests his popularity with the soldiers (XLIX. 2). See also under "et in furorem" in ch. X. The title princeps is applied to him in the sepulchral inscription of his mother: CIL VI. 886: Ossa | Agrippinae . . . . matris C. Caesaris Aug. / Germanici principis; and in CIL V. 
$5050=$ Dessau 206 from Anauni in Cisalpine Gaul his reign is termed "principatus". The two oaths of allegiance to Caligula, one from Baetica, and the other from Mysia, express an enthusiasm for the new Emperor Caligula such as Suetonius describes. (See under ch. XV.) The decree of the town of Assos in Mysia, passed in $37 \mathrm{~A}$. D. on the accession of Caligula, and engraved on the same bronze tablet which bears the oath of the Assians referred to above, is also indicative of the rejoicing of the people over the new emperor, and at the same time makes an allusion to their memory of Germanicus. The translation of this decree, as given in the Papers of the Arch. Inst. of America, 1881, p. 134-135, follows:

\section{IN THE CONSULSHIP OF GNAEUS ACERRONIUS PROCLUS AND GAIUS PONTIUS PETRONIUS NIGRINUS.}

\section{A Decree of the Assians by Vote of the People}

Since the supremacy of Gaius Caesar Germanicus Augustus, for which all men have hoped and prayed, has been proclaimed, and the world has known no bounds to its delight, and every city and every nation is eager to behold the face of the God as the greatest delight which the present age can offer to mankind,-

Be it enacted by the Senate, and the Roman merchants established among us, and the People of Assos, that an embassy be appointed from the first and best Romans and Greeks to meet and congratulate him, and to entreat him that he will hold our city in remembrance and under his protection, even as he himself promised when with his father Germanicus he first entered upon the government of our city. (The oath of the Assians follows; see XV.)

Itaque ut a Miseno movit . . . et funus Tiber prosequens: A very interesting and illuminating fragment of the Fasti Ostienses has recently been unearthed at Ostia, and appears in vol. XIV of Notizie degli Scavi, p. 182 sqq. There are several excerpts from it given in their appropriate places in this treatise, and the whole inscription will be found in the appendix. Lines 17-20 have to do with Tiberius's death and funeral: XVII K(alendas) Apr(iles) Ti(berius) Caesar Misen(i) | excessit. IIII $\mathrm{K}$ (alendas) Apr(iles) corpus | in urbe perlatum per mili[tes]. I III Non(as) Apr(iles) f(unere) p(ublico) e(latus) e(st). Cf. Tac., Ann. VI. 50; Dio 58. 28; and Suet., Tib. LXXIII. This 
is a remarkable example of the value of epigraphic evidence in correcting and supplementing our literary sources. From Suet. Tib. LXXIII we should naturally assume that Caligula entered the city with the body of Tiberius. But the remark of Dio (59.3) shows that the body was brought into the city during the night, which must have been the night following the new emperor's triumphal entry (Cal. XIII). This is not contradicted by the item of the Fasti, "IIII K. Apr. corpus in urbe perlatum per milites", since in urbe can not refer to bringing the body into Rome, but must relate to its transfer from the temple in which it was probably deposited (cf. Aug. C. 2) to the place where it lay in state; for we learn from the Fasti that four days intervened between this transfer of the body from one place to another in urbe and the public funeral on April 3. Our literary sources give us no hint of this, nor of the thirteen days which elapsed between the death of Tiberius and the exhibition of his body in Rome, nor of the fact that, as was natural, Caligula did not enter Rome in company with the body of his predecessor. The new fragment of the Fasti shows the following events in order: (i) March 16, the death of Tiberius at Misenum; (ii) March 29, the transfer of his body from one place to another in Rome; (iii) April 3, his public funeral. To these we can add from the Acta Arvalium (CIL VI. 2028c): March 28, the entrance of Caligula into Rome; and from Dio 59. 3: March 28, the entrance of the body of Tiberius during the night. Both Suetonius and Tacitus give March 16 as the clate of Tiberius's death, which is confirmed by the Acta Arvalium referred to above; therefore Dio $(57.28)$ is in error in putting the death ten days later.

-XIV.1-

ingressoque urbem . . . ius arbitriumque . . . illi permissum est: CIL VI. 2028c records Caligula's entry into the city: A(nte) d(iem) V K(alendas) Apriles: [quod] hoc die [C.] Caesar Augustus urbem ingressus est. A restored fragment of the Acta Arvalium, CIL VI. 32346e, has to do with his receiving full and absolute power by decree of the senate: [A(nte) d(iem) XV] K(alendas) Apriles | [ . . . fratrum Arvalium] nomine, quod hoc [die C. Caesar Augustus German]icus ab senatu imp- 


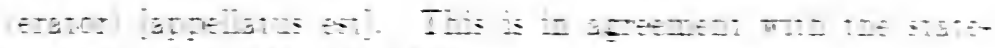
M

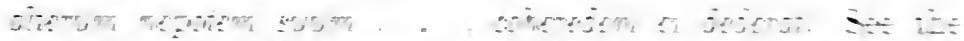

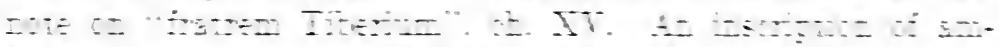

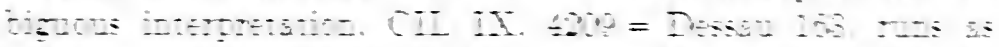

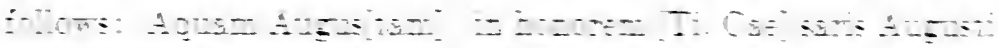

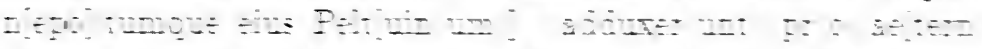

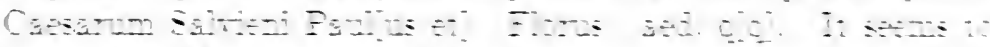

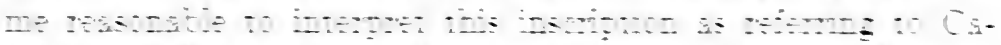


OE


ca

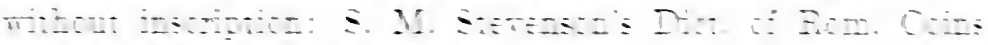

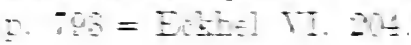

\section{$-112:-$}



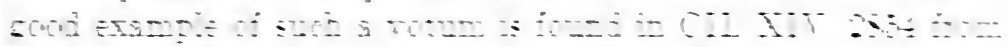

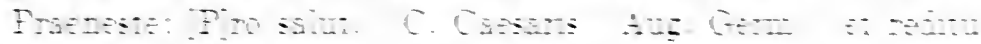

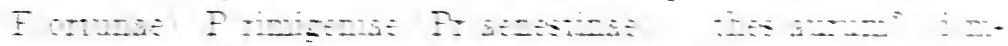

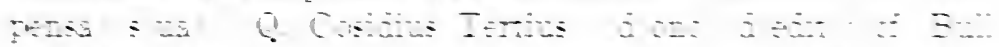





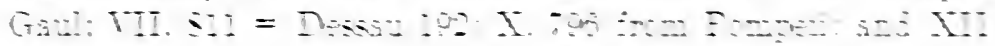

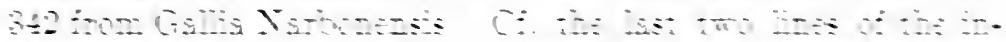

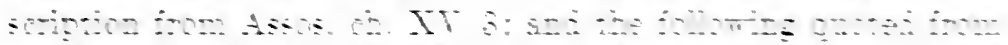

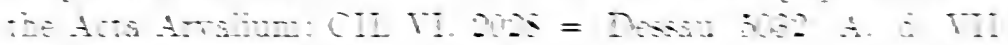

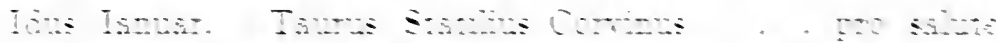

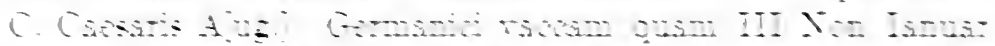
могы.



$$
-\mathrm{Tr}-
$$

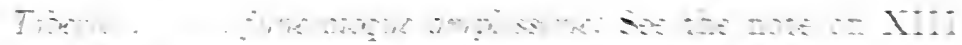

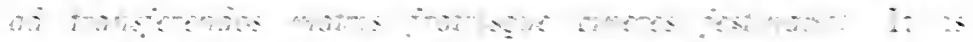

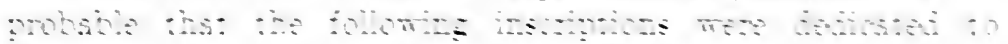



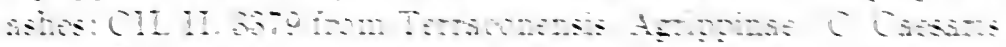
A 
166 from Laus in Cisalpine Gaul; VI. 31281 from Rome; and her sepulchral inscription from the Mausoleum of Augustus: CIL VI. 886 = Dessau 180: Ossa | Agrippinae M. Agrippae [f.], | divi Aug. neptis, uxoris | Germanici Caesaris, | matris C. Caesaris Aug. I Germanici principis. A Greek inscription from Thera may also be included among those dedicated soon

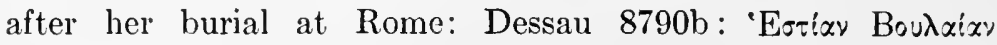

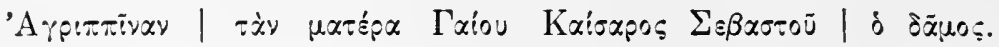
The sepulchral inscription of Nero is extant from the Mausoleum of Augustus, verifying Suetonius's statement: CIL VI. 887: Ossa | Neronis Caesaris | Germanici Caesaris f., | divi Aug. pron., flamin. | Augustalis, quaestoris.

inferiasque is annua religione publice instituit: A fragment of the Acta Arvalium in commemoration of Agrippina's birthday has been restored to read as follows: [a(nte) d(iem)] VI k(alendas) Novembr[es] | [L. Salvius Otho fl]amen et promagistro | [collegii Fratr]um Arvalium nomine in | [Capitolio] natali Agrippinae Germanic[i | Caes]aris matris C.: CIL VI. 32346.

et eo amplius matri circenses carpentumque quo in pompa traduceretur: I find in support of this statement a coin struck after her death showing on the obverse her likeness, and bearing the inscription: Agrippina M. f., mat. C. Caesaris Augusti; and on the reverse a carpentum drawn by two mules, along with the inscription: S. P. Q. R. Memoriae Agrippinae: Cohen I. p. 231, n. 1. Cf. Suet. Claud. 11; Dio 60. 33, 2; Marquardt, Privatl.2 735; and Mommsen, Staatsr..2 I, 394 sqq.

At in memoriam patris Septembrem mensem Germanicum appellavit: Suetonius relates also (D. XIII. 3) that Domitian assumed the surname Germanicus after a triumph and renamed the month of September, likewise calling it Germanicus, but from his own name instead of from that of Caligula's father. Although the following inscription from Setinum in Regio VI seems to refer to Domitian's change, at any rate the idea was Caligula's in the first place: CIL XI. 5745= Dessau 6644: C. Aetrio C. f. Lem. | Nasoni | equo publico, | in quinque decurís, | praef. coh. I Germanor., | trib. mil. leg. I Italicae, | testamento poni iussit | idemque municipib. | Sentinatib. in epulum / quod 
XVII K. Germanicas | daretur HS CXX legavit. Cf. Macrob. I. 12.36 .

Antoniae aviae . . Livia Augusta honorum cepisst . congessit: Dio (59. 3.), confirms the statement that Caligula on his accession gave to his grandmother Antonia the title of Augusta; as does also an Arval inscription of January 31, A. D. 38, which records a sacrifice on her birthday: CIL VI. 2028-e: $\operatorname{Pr}$ (idie) $\mathrm{k}$ (alendas) Februar(ias) | Taurus Statilius Corvinus promagister collegii Fratrum Arvali[um nomine] I natali Antoniae Augustac in Capitolio Iovi O(ptimo) M(aximo) bovem marem in[molavit]. Cf. also: CIL VI. $921 ;$ X. $1417=$ Dessau $150=$ Huebner 148 from Herculaneum; IGR IV. $206=$ Dessau 8787 from near Troy. A "basilica Antoniarum duarum" is mentioned in CIL VI. $5536=$ Dessau 5220. Pliny, N. H. 35. 10, and 36. 94 speaks of a temple ereeted to her, but there seems to be no literary evidence for the existence of the basiliea dedieated to the elder and younger Antonia. CIL VI. 921 eonfirms Dio's statement (59.3) that she was called priestess of the deified Augustus: Antoniai | Augustai | Drusi | sacerdoti diţi | Augusti | matri Ti. | Claudi | Caisaris Aug., p. p. Cr. Eckhel VI. 179, and Cohen I. p. 222 for similar allusions to her.

patruum Claudium . . collegam . . . assumpsit: This refers to the first consulship of both Caligula and Claudius, which began the first of July in $37 \mathrm{~A}$. D. It is recorded in the Fasti Arvalium for that year: CIL I2. p. 71; V. $24=$ Dessau 198 from Pola: [Ti. C]laudio | [Dru]si German. f. I Neroni Germanico | auguri, sodali Aug., | sodali Titio, cos; and in the Fasti of Ostia: Notizie degli Scavi XIV (1917), p. 182; K(alendis) Iul(iis) | C. Caesar | Ti. Claudius Nero G[erm(anicus)]. See the note on XVII. 1.

fratrem Tiberium die virilis togae adoptavit: Several inscriptions refer to Tiberius (Gemellus): CIL V. 4311 from Brixia; V. 7598 from Alba Pompeia in Cisalpine Gaul: Ti. Caesari Drusi f., | Ti. August[i n.], | divi Augusti pron[ep]., | P. Varius P. f., Aem. | Ligus filius; IGR III. $997=$ CIG 2630 from the neighbourhood of Salamis in Cyprus, mentioning him with his twin brother Germanicus, who died in $23 \mathrm{~A}$. D. at the age of four. His image is stamped on coins of 23 A. D.: Eckhel VI. 204. In none of the inscriptions referred to above, nor even in his mortuary inseription, is there any trace of the adoption 
mentioned by Suetonius; the last named reads as follows: CIL VI. $892=$ Dessau 172: Ti. Caesar | Drusi Caesaris f., | hic situs est. Hirschfeld, Herm. 25. p. 366, n. 4, thinks that this adoption was not considered as being serious on the part of Caligula, and this opinion is confirmed by the inscription just cited. Cf. XIV. 1. See also Dio 59.1.

\section{$-\mathrm{XV} .3-$}

De sororibus auctor fuit, ut omnibus sacramentis adicerentur: A mutilated passage, CIL VI. 2028-b = VI. 32344 from Rome, has been restored by Mommsen to read: Quod bonum felixque sit C. Caesari sororibusque eius, basing his restoration on this passage in Suetonius. Henzen's restoration, although different, is the same as regards the mention of Caligula and his sisters; it reads as follows: Q[uod bonum faust]um [felix fortunatum salutareq(ue) sit C. Caesari Aug.] | Ger[manico ipsi so]rori[busq(ue) eius] p[(opulo) R(omano) Quiritibus fratribusque Arvalibus] | mih[ique: sacri]ficium in [luco domoque] | C. C[aesa]ris Augusti German[ici magistri erit] . . . . On this oath and on oaths in general taken in the name of Caligula and his sisters, see Eph. Epigr. V. p. 154 sqq. Cf. Dio 59.3. A long inscription from Aritium in Lusitania, CIL II. $172=$ Dessau 190, is interesting in this connection, being an oath of allegiance to Caligula taken on May 11, A. D. 37, just fifty-two days after the death of the emperor Tiberius. Being the longest and best preserved Latin inscription of this character relating to Caligula, I reproduce it in its entirety:

C. Ummidio Durmio Quadrato

$\operatorname{leg}(a t o)$ C. Caesaris Germanici imp(eratoris) pro praet(ore).

Iusiurandum Aritiensium.

Ex mei animi sententia, ut ego ís inimicus cro, quos C. Caesari Germanico inimicos esse cognovero, et si quis periculum ei salutiq(ue) eius in[f]ert in[f]er[e]tque, armis bello internicivo terra mariq(ue) persequi non desinam, quoad poenas ei persolverit, neq(ue) me [neque] liberos meos eius salute cariores habebo, eosq(ue), qui in cum hostili animo fuerint, mihi hostes esse 
ducam; si s[cie]ns fa[ll]o fefellerove, tum me

liberosq(ue) meos Iuppiter optimus maximus ac divus Augustus ceteri(que) omnes di immortales expertem patria incolumitate fortunisque omnibus faxint.

[A. d.] V Idus Mai[as] in

Aritiense oppido veteri Cn. Acceronio

Proculo C. Petronio Pontio Nigrino cos., $\operatorname{mag}$ (istris)

Vegeto Tallici, . . . . ibio . . . arioni.

The official carcer of the same C. Ummidius Durmius Quadratus appears in CIL X. $5182=$ Dessau 972 .

Another oath of allegiance to Caligula, taken by the people of Assos in Mysia upon his accession in $37 \mathrm{~A}$. D., is preserved on a bronze tablet $(0.54 \times 0.38 \mathrm{~m}$.), which bears also a decree passed by the town of Assos (see under ch. XIII for this decrec). The Greek text of this inscription appears in Eph. Epigr. V. p. 155, and also in the Papers of the Arch. Inst. of America (Classical Series), 1881, p. 133-134, where there are also a facsimile and a translation of it. The translation of the oath of the Assians reads as follows:

\section{Oath of the Assians}

We swear by the Saviour Zeus and Deity Caesar Augustus, and by the pure Virgin whom our fathers worshipped, that we will be faithful to Gaius Caesar Augustus and all his house, and that we will consider those our friends whom he shall prefer, and those our enemies whom he shall declare. May it be well with us if we are true to our oaths, and may it be otherwise if we are false to them.

These offered themselves as ambassadors at their own expense:

Gaius Varius Castus, son of Gaius, of the tribe Voltinia,

Hermophanes, son of Zoilus,

Ctetus, son of Pisistratus,

Aeschrion, son of Calliphanes,

Artemidorus, son of Philomusus,

who also invoked Jupiter Capitolinus for the safety of Gaius Caesar Augustus Germanicus and made sacrifice in the name of the city.

Ducentesimam auctionum Italiae remisit: On the reverse of three coins struck during the reign of Caligula are stamped the letters R. C. C., which are generally interpreted as referring to 
this remission: Remissa ducentesima: Cohen I. p. 237, nos. 5 and 6 , and p. 238, no. 7. Cf. Dio 59.9.

ac si quibus regna restituit: e. g., Agrippa the Great, to whom he gave the tetrarchies of Abilene, Batanaea, Trachonitis, and Auranitis, and also the title of king (Jos. Ant., 18. 6, 10; 7, 2). Two inscriptions from Helbone in Syria may be construed as referring to the close friendship which Agrippa enjoyed with Caligula and Claudius: IGR III. 1089 and 1090, in which he is

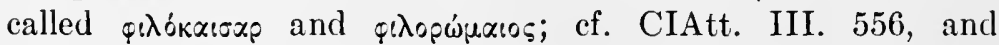
Madden, Jewish Coinage, p. 103, where similar titles occur. Another prince whom Caligula thus aided by placing him on the throne of Ituraea in $39 \mathrm{~A}$. D. was Sohaemus, and the following inscription from Heliopolis in Syria throws some light on the subject: CIL III. $14387 \mathrm{a}=$ Dessau 8958: Regi magno | C. Iulio Sohaemo | regis magni Sam/sigerami f., philo/caesari et philo|[r]ohmaeo (sic) honora|t[o ornam.] consulari | b ! ! ! ! ! | patrono coloniae | II viro quinquenn: | L. Vitellius L. f., | Fab. Sossi[a]nus. (A cohort of Ituracans is mentioned in an inscription honouring Caligula: CIL III. 14147.) I can find no information as to the origin of this prince, but it appears from this inscription that he assumed the name of $\mathrm{C}$. Iulius in honour of Caligula and the Julian family. See Tac. Ann. 12. 23, and Dio 59. 12, 2. That Caligula restored the sons of Cotys to their throne is apparent from a long Greek inscription from Cyzicus, IGR IV. 145, in which he is called o vśos "H $\mathrm{H} \cos \Gamma \alpha \dot{\alpha}: 05$

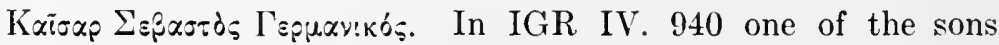
of Cotys, Rhoemetalces, who was king of Thrace during the


Cf. IV. 941. See Dio 59. 12

Antiocho Commageno: An inscription from Chios calling

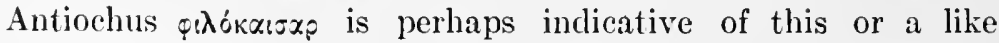
act of munificence on the part of Caligula: IGR IV. 940. Cf. 945 and 946 from Chios; Eckhel III. p. 255 and 257.

\section{-XVII. 1-}

Consulatus quattuor gessit: There is abundant evidence from inscriptions for the four consulships of Caligula, and each one will be treated separately, as in the text of Suetonius:

primum ex Kal. Iul. per duos menses: In the Fasti Arvalium for 790 a. u. c. $=37$ A. D. Caligula and Claudius are named as 
consules suffecti: CIL I ${ }^{2}$. p. 71; and in the Fasti Ostienses of the same year the consulship is recorded as follows: $\mathrm{K}$ (alendis) Iul(iis): C. Caesar | Ti. Claudius Nero G(ermanicus): Notizie degli Scavi, vol. XIV, p. 182. (See appendix for the whole inscription.) This inscription exactly confirms Suetonius's statement that Caligula's first consulship lasted two months, for it not only gives July 1 as the date of his assuming the office, but also names the two consuls succeeding him and Claudius (a fact not known prior to the discovery of this inscription) and gives September 1 as the date of their entry into office. CIL X. 796 undoubtedly refers to Caligula's first consulship: I(ovi) [O(ptimo)] M(aximo). I Pro salute [C. Ca]esaris Augusti Germani[ci i]mp. pont. max. | tribunic. p[ote]stat. consulis |. This consulship is probably the one noted in CIL XII. 2331 from Gallia Narbonensis: [C.] Caesare Aug. | [Germanico] imp., pont. max., | trib. potest., cos., | ratiari | Voludnienses. Coin no. 31, Cohen I. p. 241, also dates from this consulship. Cf. Dio 59. 6.

secundum ex Kal. Ian. per $X X X$ dies: Caligula is named consul for the year 39 A.. D. with L. Apronius Caesianus as his colleague in the Fasti Antiates, CIL I2. p. $247=\mathrm{X} .6638$; and again in the Acta Arvalium, VI. $2029=32346$, which record a sacrifice to the Capitoline triad in honour of Caligula upon his assuming the office. Cf. also II. $4716=$ Dessau 193, and 6208 from Baetica; 6234 from Terraconensis; and III. 14147 ${ }^{1}$ (ch. XLIX. 2).

tertium usque in Idus Ian., . . . iniit solus: In the Fasti Antiates, CIL I2. p. $247=$ X. 6638 , he is named without a colleague as consul for the year 40 A. D.; again in II. 4639 and 4640 , columns from the viae publicae of Lusitania; and in II. 6233, a column from the viae publicae of Terraconensis; and on the following coins: Cohen I. p. 233, n. 5; p. 237, n. 5: cos. des. III; and p. 237, n. 6. Caligula's name appears as follows at the beginning of a long carelessly written Greek inscription from the neighbourhood of Philadelphia in Lydia: Denkschriften der Kaiserl. Akad. der Wiss. in Wien, Phil.-Hist. Kl., LIII, 2 (1908), p. 49 = Rev. Arch. IV ser. vol. 14 (1909), p. 505:

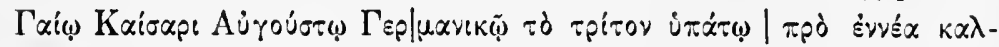

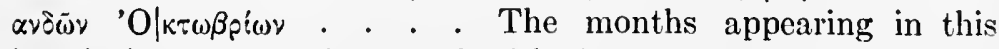
inscription are not in accord with that of his third consulship, but the year may well be the same, $40 \mathrm{~A}$. D. The mention of 
the month October is either an error, or must be accounted for by the fact that the calculation was based on Caligula's being the consul ordinarius for the year.

quartum usque septimum Idus easdem: $\mathrm{He}$ is called consul designatus IIII in CIL II. 4639 and 4640 from Lusitania. Several coins refer to his fourth consulship, which lasted a week: Cohen I. p. 233, n. 7 ; p. 238, n. 8 ; and p. 245, n. 8.

\section{-XVII. 2-}

Congiarium populo bis dedit trecenos sestertios: Suetonius undoubtedly refers to the two largesses which Caligula gave to the people in the first year of his principate, which are recorded in the recently discovered fragment of the Fasti Ostienses of 37 A. D.: K(alendis) Iun(iis) cong(iarium) d(ivisum) LXXV. XIIII | Kalendas Aug(ustas) alteri $\mathrm{XXXV.} \mathrm{For} \mathrm{the} \mathrm{entire}$ inscription see the Appendix, and for a discussion of the gram. matical construction of this excerpt see Notizie degli Scavi XIV. p. 194.

\section{-XVIII. 1-}

in amphitheatro Tauri: We have inscriptions naming several of the functionaries of this amphitheatre: CIL VI. $6226=$ Dessau 5156: Charito custos de Ampitheat. (sic); $6227=$ Dessau 5157: Menander 1. | Ostiarius | ab Amphitheatr; 6228: Euenus Chresti | Auctiani vicar. | de Amphiteatro (sic) v. a. XXV; and 6372: T. Statilius | Dasius Tauri 1. | ad vestem avi., all from Rome and found in the vicinity of the site of the amphitheatre. Cf. VI. 9412-9415 incl., and 33185. The name of Taurus is of frequent occurrence in inscriptions, and some of them may be of interest here: we learn from the Fasti Biondiani, CIL I². p. 65, that he was consul suffectus for the year 717 a. u. c., that he was proconsul of Africa and had a triumph on June 30, 720 a. u. c.: Acta Triumph., Barberina, et Capitolina: CIL I'; that he was consul ordinarius twice, (1) with Marcus Agrippa in 717 a. u. c.: CIL IV. 2437 from the vicinity of Stabiae, (2) with Augustus in 728 a. u. c.: XIV. 2240 from Mons Albanus in Latium, and II. 3556 from Ilicum in Terraconensis: T. Statilio | Tauro imp. | III, cos. II | patrono. Cf. also CIL III. 605, and X. $409=$ Dessau 893a. 


\section{-XVIII. 2-}

Scaenicos ludos et assidue et varii generis ac multifariam fecit: A fragment from the neighbourhood of Stabiae, CIL IV. 669, is perhaps from a programma of such an exhibition given by Caligula.

\section{-XVIII. 3-}

interiecta modo Africanarum venatione: Dio (59. 7) says that Caligula exhibited four hundred bears and a like number of panthers ("Africanae" in Latin) at the dedication of the temple of Augustus in $37 \mathrm{~A}$. D. The practice was not an uncommon one, and the following inscriptions contain allusions to such displays of African wild beasts: CIL IX. $2350=$ Dessau 5059 from Allifae, $2237=$ Dessau 5060 from Telesia; X. $339=$ Dessau 5061 from Salernum, and Dessau $9406=$ Comptes rendus de l'Acad. des inscr., 1910, p. 135, from Carthage. Cf. Dio 59. 13.

Gelotiana: The "domus Gelotiana" is mentioned in CIL VI. 8663: Symphoro / tesserario / ser(vo) Caesaris | de domo Gelo|tiana fecit | Philodespotus | ser(vus) Cacsaris | ex Hermaeó | fratri b(ene) m(erenti).

-XIX. 3-

Thrasyl<l> us: See Tib. XIV. 4, and the note in Holtzhausser, p. 19 .

\section{$-\mathrm{XXI}-$}

Opera sub Tiberio semiperfecta, templum Augusti . . . absolvit: Cf. Tib. XLVII. On the reverse of a coin of Caligula, Cohen I. p. 238, Caligula is pietured standing and saerificing a bull before an altar in front of a hexastyle temple, which is clearly intended to be that of Augustus mentioned by Suetonius, for the inscription to the sides of the temple is: Divo Aug. S. C. This coin undoubtedly commemorates Caligula's dedication of the building in $37 \mathrm{~A}$. D. described by Dio (59. 7, 1). Tacitus, on the other hand, states that Tiberius completed the structure (Ann., VI. 45, 2), and he is confirmed also by a coin of the year 34 on which a similar representation of the temple is found, seemingly indicating that it was finished in that year: Cohen I. p. 195, n. 68. Frequent mention of 
this temple is found throughout the Acta Arvalium, e. g., CIL. VI. $2041=$ Dessau 229, and $2042=$ Dessau 230 .

Incohavit autem aquae ductum regione Tiburti . . Claudio - . peractum: It seems that Caligula did little more than begin the Claudian Aqueduct, or there would very probably be inscriptions that recorded his part in the great undertaking. The following, apparently, refers to the dedication during the principate of Claudius: CIL VI. $1256=$ Dessau 218: Ti. Cl. Drusi f., Cais. Aug. Germ. . . . | aquas Claudiam ex fontibus qui vocabantur Caeruleus et Curtius a milliario XXXXV, item | Anienem novam a milliario LXII sua impensa | in urbem perducendas curavit . . . . . Cf. 1257-8. Frontinus (1.13) and Pliny (N. H. 36. 122) state that Caligula began two aqueclucts.

Destinaverat el Sami Polycratis regiam restituere: The following inscription from Samos is interesting in this connection:

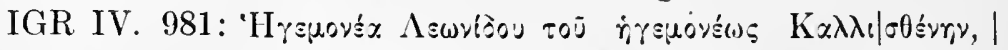



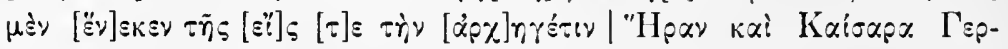

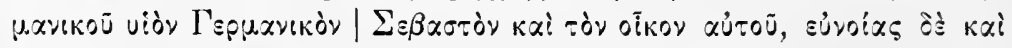

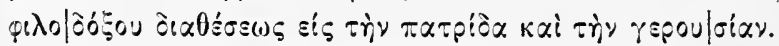

An inscription from Bononia, CIL XI. 720, alludes to some other construction work undertaken by Caligula, it would seem, though his name has been erased: Divus Aug. parens | dedit !!!!!!!!!!!! Augustus | Germanicus !!!!!! | refecit, I (and five lines added later showing the nature of the structure, perhaps:) In huius balinei lavation. HS $\overline{\mathrm{CCCC}} \mid$ nomin. C. Aviasi T. f. Senecae f. sui . . . etc. On the other hand, one inscription, at least, shows traces of his neglect of public works, in contrast to his building craze: CIL VI. $1252=$ Dessau 205: Ti. Claudius Drusi f. Augustus . . . | arcús ductús aquae Virginis disturbatos per C. Caesarem | a fundamentís novos fecit et restituit.

Mileti Didymeum peragere: Dio (59. 28) says that Caligula ordered the temple of Apollo to be restored in order that he might appropriate it to his own worship. But the Didymeum, a decastyle temple, must not be confused with the hexastyle temple of the Gaius cult which was erected at Miletus, as is evident from the following inscription: Abhandl. der Königl. Preuss. Akad. der Wissen. Phil.-hist. Klasse, 1911, p. 65= Rev. Arch. XX (1912), p. 440: 


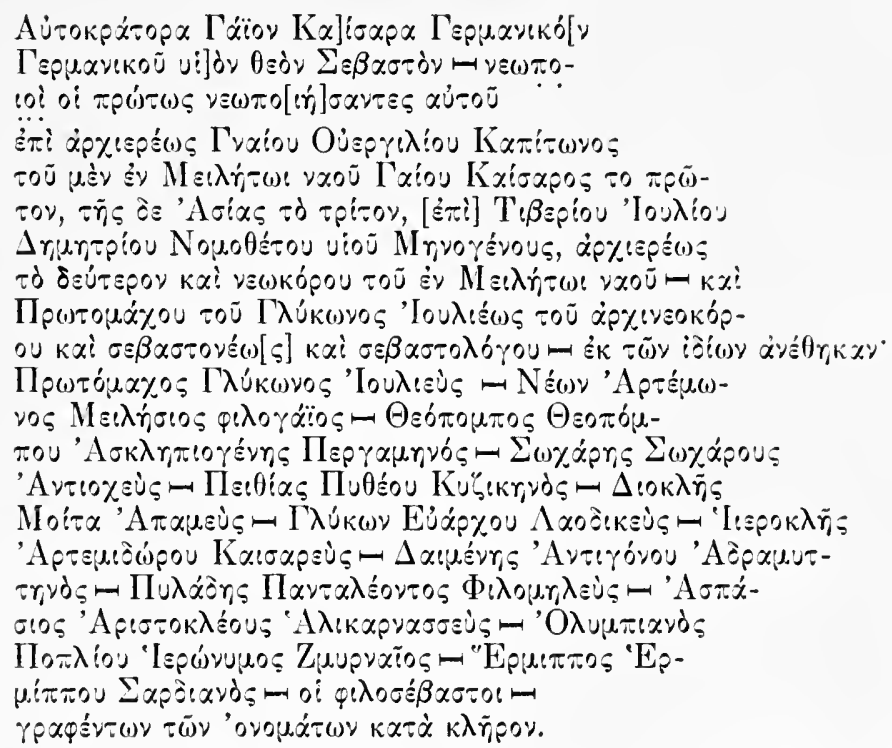

In the light of this inscription, the statement of Dio appears to be an error; and if Caligula had intended to complete the temple of Apollo, it was hardly for the worship of himself. The Gaius temple is reproduced on coins: see Head, Cat. British Museum: Ionia, p. 198.

\section{-XXII. 1-}

de principe: See the note on XIII.

"pius" el "castrorum filius"et "pater exercituum" ct "optimus maximus Caesar" vocabatur: None of these titles is mentioned in authentic inscriptions, so far as I have been able to ascertain, but a false inscription represented as having come from Baetica shows how cleverly the forger used the literary sourees, perhaps this very passage: CIL II. 150*: c. caesar pius, castorum (sic) f., pater exercituum, opt.l max. caesar. There is, however, a Greek inseription from the island of Calymna honouring Caligula with the cognomen Eugs $\beta r_{i}$, the equivalent of the Latin "pius": IGR IV. 1022. This inseription dates back to the year $18 \mathrm{~A}$. D. when Caligula was in the East with Germanicus, and does not lend support to Suetonius's list of imperial cognomina. It is interesting and curious that Suetonius fails to mention the only cognomen for which there is sure epigraphic evidence, viz: Germanicus. 
Templum etiam numini suo proprium: I find no epigraphic evidence for such a temple at Rome, but there was one erected to Caligula's gochead at Miletus, already referred to in ch. XXI. In the Acta Arvalium for the years of his principate, as well as in other inscriptions, the temple of Augustus which he completed (ch. XXI) is most often referred to in connection with sacrifices in which Caligula participated.

In area Capitolina novae domus fundamenta iecit: Sec "Caligula" in the index of Huelsen's Forum Romanum.

-XXIII. 1-

Agrippae se nepotem neque credi neque dici . volebat: But Agrippina's mortuary inscription, which was in all probability set up by Caligula (ch. XV. 1), and a coin of Caligula (Cohen I. p. 241, n. 31) reading: C. Caesar Germanici f., M. Agrippae n., divi Aug. pron., August. Germanicus, pon. max., tr. potest., cos., would seen to indicate that this was probably only a passing whim of his. See under eh. L.

Actiacas . . . victorias". . vetuit sollemnibus feriis cclcbrari: Two excerpts from the fasti convince us that the battle of Actium was celebrated by decree of the scnate, (1) Fasti Arvalium for September 2, between 742 and 767 a. u. c.: CIL $I^{2}$. p. $214=$ VI. 2295 : Ex s. c. | feriae Imp. Caesaris h. c. | quod eo die vicit Actium; (2) Fasti Amiternini for September 2, some ycar after 769 a. u. c.: CIL I². p. 244: Fer. ex s. c. quod eo die Imp. | Caes. Divi f., Augustus | apud Actium vicit | se et Titio cos. The battle itself is recorded in the Fasti Venusini for 723 a. u. c.: CIL I ${ }^{2}$. p. $66=$ IX. 422 , and in the Fasti Amiternini for the same year: CIL IX. 4191. Cf. V. $2501=$ Dessau 2243; XI. $623=$ Dessau 2672 .

-XXIII. 2-

materno avo . . . Aufudium Lurconem: Several inscriptions which mention Livia's mother throw some light on this statement: CIL II. 1667 from Tucci: Alfidi[ae] ma[t.] Augustae; IX. 3661 from Marruvium: Alfidia M. f., mater Augustae; and IGR

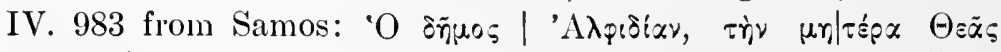

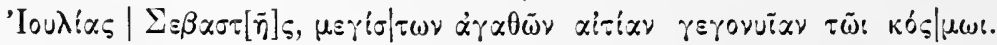
Cf. also 982 from Samos, mentioning Livia's father, Marcus Livius Drusus Claudianus. From these inscriptions we learn 
that she was the daughter of M. Alfidius and that the name Aufidius is an error on the part of Suetonius. Pliny (N. H. 10. 45) and Varro (R. R. 3. 61) show Aufidius Lurco to be an altogether different person. Horace (Sat. I. 5. 34) ridicules a certain Aufidius Luscus of Fundi, a thing which he would hardly have done had Aufidius been of the same family as Livia. See the note on this passage in Lejay's Satires of Horace, p. 155.

Aviae Antoniae . . . per . . . indignitates . . . causa extitut mortis: The recently discovered fragment of the Fasti Ostienses gives May 1, 37 A. D. as the date of Antonia's death: Notizie degli Scavi, vol. XIV (1917), p. 182, lines 21-22: K(alendis) Mais Antonia diem suum obi(it). She was just seventythree years and three months old. Dio (59. 3) supports Suctonius's statement relative to the suspicion that she met a violent death.

nec defunctae ullum honorem habuit: But the succeeding anniversary of her birthday, coming on January 31,38 A. D., just nine months after her death, was observed with sacrifices in her honour, and the following record of it was made in the Acta Arvalium: CIL VI. 2028c: Pr(idie) K(alendas) Februar(ias) । Taurus Statilius Corvinus promagister collegii fratrum Arvali[um nomine] | natali Antoniae Augustae in Capitolio Iovi $\mathrm{O}$ (ptimo) M(aximo) bovem marem in[molavit]. Note that she here has the title of Augusta, which she had refused during her life-time, according to Suet., Claud. XI; cf. Dio 59. 3 and 60.5. Suetonius evidently uses the word 'honorem' in this passage to signify special funeral honours, such, for example, as Caligula had paid to the memory of Tiberius.

\section{-XXIII. 3-}

Fratrcm Tiberium . . . interemit: Sec the note on XV. 2 Silanum: Sce the note on XII. 1.

Lucio Cassio Longino consulari: According to the Fasti Arvalium, CIL I². p. 71, he was consul with M. Vinicius in 783 a. u. c. The Fasti Nolani for the sane ycar verify this: CIL X. 1233: L. Cassius Longinus M. Vinicius cos.; ef. V. 54 from Pola in Regio $\mathrm{X}$ and 583 from Tergeste in Cisalpine Gaul, and VI. 29681 from Rome. Vinicius was Livilla's husband. See the note on Livilla, ch. VII. 


\section{-XXIV. 2-}

Eadem defuncta . . nisi per numen Drusillae deieravit: Drusilla's death occurred June 10, 38 A. D., according to the lately found fragment of the Fasti Ostienses: Notizie degli Scavi XIV (1917), p. 182: (line 29) IIII Idus Iun(ias) Drusilla excess(it). (See Appendix.) In a number of inscriptions she is referred to as the "deified Drusilla"; in fact it is the general appelation for her after her death: CIL V. 7345 from Caburrum in Cisalpine Gaul: . . . Secunda . . . I [flam]inica Divae Drusillae | . . ; XI. 1168 from Veleia: Divae Drusil[lae] | Germani[ci] Caesari[s f.]; XI. 3598 from Caere: Divae Drusillae sorori | [C. Caesaris] Augusti | Germanici; XIII. $1194=$ Dessau 197 = Huebner 193 from Avaricum in Aquitania: Pro salute | Caesarum et p. R. | Minervae et Divae | Drusillae sacrum | in perpetuum | C. Agileius Primus | IIIII vir Aug., c(urator) c(ivium) $\mathrm{R}$ (omanorum), d(e) s(ua) p(ecunia) d(edit); XIV. 3576 = Dessau 196 from Tibur: [Di]vae Drusillae | sacrum | [C.R]ubellius C. f. Blandus | [q.] divi Aug., tr. pl., pr., cos., | [pr]ocos., pontif; cf. IX. 1107, a fragment which evidently refers to her: ..... Caesaris sorori | .... i. p. f. Flaccus et Pertic . . $\mid \ldots \ldots \ldots$-va pecunia fac. cur. It seems that her birthday was celebrated with sacrifices to her godhead: CIL VI. 32345, a fragment of the Acta Arvalium for some date between 38 and 41 A. D.: . . . I ante tem[plum divi Augusti novum] | divae $\mathrm{D}$ [rusillae sorori Germanici Aug.] | vaccam .

In Greek inscriptions from Asia she is accorded divine honours even before her death: IGR IV. $78=$ I. Gr. XII. ii. 172 from

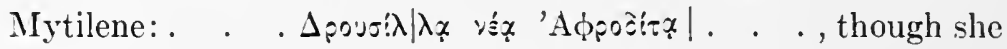
may have died just a short time before the inscription was

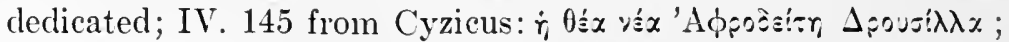

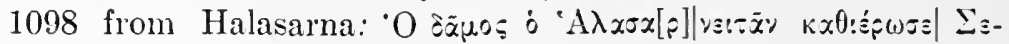




in causa Acmili Lepidi: There is an allusion to the conspiracy in which Lepidus was involved with $\mathrm{Cn}$. Lentulus Gaetulicus in the Acta Arvalium of the year 39 A. D.: CIL VI. $2029=$ 32346: A. d. VI K. Novemb. I ob detecta nefaria con[silia in C. Germa|nic]um Cn. Lentuli Gae[tulici]. See the note on Cn. Lentulus Gaetulicus, ch. VIII. 1. 


\section{-XXV. 1-}

Liviam Orestillam C. Pisoni nubentem: I find no inscriptions in which she is mentioned, but Piso's name oceurs several times in the Acta Arvalium: CIL VI. 2028, 2030, 2039, 2048, all from Rome. III. 12794 from Dalmatia refers to him: [P]isone leg. pro pretore (sie) [Ti.] Claudi Caesaris [Aug.], and he may be the person who appears in XIV. 3437.

$-\mathrm{XXV} .2-$

Lolliam Paulinam: Her birthday seems to be the one commemorated in the Acta Arvalium of 39 A. D. : CIL VI. $32346 \mathrm{e}=$ Eph. Epigr. VIII. p. 322, n. 5. Cf. Dio 59. 12; and Eph. Epigr. I. p. 109 sq., and pp. 218-219. The following inseription found near Gallipoli in Thrace is interesting in connection with her: Bull. de corr. hellén., 1900, p. 167: Lolliae M. f. Pauli[nae] Pa[ul]us Antoniu[s ! ! ! ! ! ] | Bosp[o]rus et Aeliu[s] | Apollinius II viri qui ! ! ! ! | d. d. At first sight one might conclude that this is dedicated to the wife of Caligula, inasmuch as she was the daughter of Marcus Lollius who was sent to Thrace by Augustus in $16 \mathrm{~B}$. C. to aid Rhoematalces, uncle and tutor of the sons of King Cotys (Cf. XVI. 3); and it seems only natural that her marriage with the emperor should have been com. memorated in Thrace. But Seure thinks (l. c.) that the name of Aelius and the absence of any title designating Lollia as empress-eleet seem to preelude assigning it to a date prior to the epoch of the Antonines. This inseription seems to be our locus elassicus for the existence of duoviri quinquennales at Gallipoli. A forged inseription eomes from Lugdunum, where Caligula entered upon his third consulship (XVII. 1) in 40 A. D.: CIL XIII. 283*: Lollia Pauli. C. Ca. imp.

C. Memmio consulari: On the monuments he is called Publius instead of Gaius. From the following inscription it appears that he was proconsul of Asia, a faet not elsewhere recorded, when Caligula sent for his wife: CIL III. $7090=$ Dessau 962 from Pergamum: [P. Memmio P. f.,] Regulo cos., procos., legat. Augu[storum . . . . . . fra]tri Arsali, sanctissimo et iustissimo .... . . patrono semper bene de se merito . . . . [eurante] Potamone ....... Cf. Dio 58. 25. Other inscriptions relating to him are CIL. III. $2028=8753 ;$ X. $1233=$ Fasti 
Nolani, 6639 = Fasti Antiates; Bull. Archéol. du Comité des Travaux Historiques, 1911, p. 138, and 1913, p. 220; 'E $\pi$ r


and pp. 218-219.

\section{-XXV. 3-}

Caesoniam neque facie insigni. . . amavit: Mommsen argues that her name has been erased from the Acta Arvalium for June 2-6, $40 \mathrm{~A}$. D. and restores the passage to read as follows: CIL VI. 32347: ob natalem [Caesoniae | C. Caesaris Germanic(i) Aug(usti)] Iovi bovem marem . . . . Two coins of Caligula from Nova Carthago are generally thought to bear a likeness of Caesonia, though they are not stamped with any name: Cohen I. p. 247, nos. 1 and 2. Cf. Dio 59.23.

$-\mathrm{XXV} .4-$

Infantem . . Minervae gremio imposuit . . commendavit: That Caligula especially revered Minerva may be gathered from the following inscription dedicated after the death of his favourite sister Drusilla, for whom his infant daughter was named: CIL XIII. 1194 = Dessau 197 from Aquitania: Pro salute | Caesarum et p. R. | Minervae et Divae | Drusillae sacrum | in perpetuum . . . . His sister Livilla was worshipped in close relation with Minerva Victrix at Pergamum:

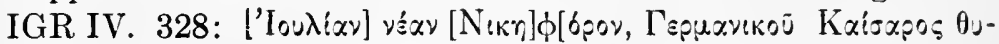

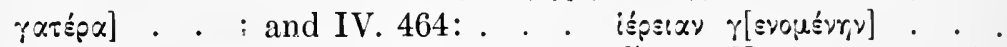

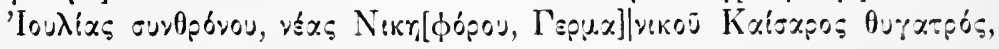

Ptolemaeum regis Iubae filium: The Fasti Praenestini for April of a year between 757 and 763 a. u. c., CIL I ${ }^{2}$.p. 235, record Augustus's victory over Juba, the father of the Juba mentioned by Suetonius, which was the beginning of the relationship existing between the later emperors and the family of Mauretanian kings: Ludi f. q. e. d. C. Caesar C. f. in Africa regem [Iubam] | V[icit]. Tituli of the freedmen of Iuba and Ptolemaeus are found not only in Africa but also at Rome, in consequence of their having lived at Rome in the imperial 
household: cf. CIL VI. 10110 and 20409. Other inscriptions mentioning Juba and Ptolemaeus are CIL VIII. $9257=$ Dessau 841 from Icosium, doubtless dedicated after Caligula had put Ptolemaeus to death: [R]egi Ptolemae[o] | reg. Iubae f., | L. Caecilius Rufus | Agilis f., honoribus | omnibus patriae | suae consummatis | d. s. p. f. c. et consecravit,; VII. 9342: Geni[o] | regis Pto[lemaei]l regis [Iubae f.] ; VIII. 9247, 9344, 9348, 9349, 9350, 9351; IGR III. 612 from Xanthus in Lycia; and the following which gives the line of descent of Juba: CIL II. 3417= Dessau 840 from Nova Carthago: Regi Iubae re[gis] | Iubae filio, regi[s] | Iempsalis n., regis Gau[dae] | pronepoti, regis Masiniss[ae) i pronepotis nepoti, | II vir quinq., patrono / coloni; cf. Eckhel IV. 158, and Eph. Epigr. V. 978, 1013, 1014, 1015, 1017, $1018,1019,1020,1021$. Several coins of Juba and Cleopatra are given in Head's Historia Numorum, p. 747. Cf. Dio 59. 25.

\section{-XXVII. 3-}

per Genium suum: Sacrifices were offered to his Genius: CIL VI. 32345; see ch. XXV. 4. An inscription from Rome dedicated in $38 \mathrm{~A}$. D. reads: Pro salúte et páce et / victóriá et Genió | Cáesaris Au[gusti]: CIL VI. $811=$ Dessau 192. The brief inscription, XII. 3052 from Nemausus: G. C. N. | Ascanius ser. has been interpreted: $\mathrm{G}$ (enio) $\mathrm{G}$ (ai) $\mathrm{N}$ (ostri) $\mid$ Ascanius ser(vus).

-XXX. 2-

ut Seiani clientis: For the conspiracy of Scjanus sce ch. XII. 1.

-XXXVI. 1-

Mnesterem pantomimum: Dessau thinks he is meant in CIL VI. 20139: Ti. Iulio | Aug. l. | Mnesteri, which indicates that he was manumitted by the emperor Tiberius.

Valerius Catullus, consulari familia iuvenis: He may be the Catullus named in CIL XIV. 2095, a fragmentary inscription from Lanuvium: [Di]vo Aug. | L. f. Valerius Catull. co[s] .... Catullus pontif ........ At any rate, the inscription supports the consulari familia of Suetonius. One niember of this family, Sextius Tedius Valerius Catullus, was consul in 31 A. D., and another, Lucius Valerius Catullus, Messalinus, was consul in 73 A. D. See Licbenam's Fasti Cos. Imp. Rom., pp. 11, 15, and 87 . 


\section{-XLIII-}

expeditionis Germanicae impetum cepit: It is very likely that the inscription, CIL VI. 811, quoted above under XXVII, was dedicated just prior to or during the German "campaign" of Caligula; the same being equally true of CIL XIV. 2854 from Praeneste: [P]ro salut. | C. Caesaris | Aug. Germ. | et reditu | He set out before November of 39 A. D., for the preliminary sacrifice was offered on October 27: CIL VI. 2029, quoted under ch. VIII. I. An inscription from Koula in Asia, IGR IV. 1379 = Dessau 8791 commemorates this "campaign":

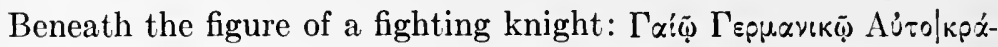




described under ch. IX, may refer to an incident of this expedition, as e.g. that recorded in XLIV.1. This expedition is closely related to the conspiracy referred to in VIII. 1. See Janssen's "Ad Expeditionem Gai Principis in Germaniam", Mnemosyne, New Series vol. 48 , pt. 2 (1920).

\section{-XLIX. 2-}

proposuerat . . Alexandream commigrare: The existence of several inscriptions probably set up by his agents in Alexandria and vicinity may be indicative of his proposed exodus from Rome: IGR I. $1057=$ CIG 4963: "Erous $\delta$ " [Гxiou]




Dessau (Prosop. Imp. Rom. III. p. 436, no. 524) thinks that the name of Caligula was erased purposely; IGR I. 1086: "Erous

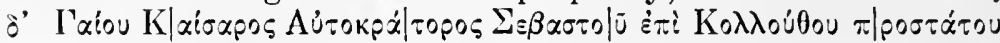
ouvó:รoul . . . ; and IGR I. $1248=\mathrm{CIG}$ add. $4716 \mathrm{~d}, 48$. All three of these inscriptions may be dated in the latter part of his principate. An inscription on the base of a statue, undoubtcdly of Caligula, found in situ before a temple at Syrênê in Egypt is of interest here, though it may not be a proof of the statement of Suetonius: CIL III. 14147': C. Caesari Aug. Germanico Divi. Aug. I pronepoti, Ti. Caesaris Aug. n., Germanici Caesaris f., / cos. II, trib. protest., pontif. maximo, imp., patri patriae, I per C: Vitrasium Pollionem, praef. Aegyp., cohors Ituraeor. | cui praest L. Eienus, L. f., Fal., Saturninus, anno III C. Caesaris Augusti / Germanici, IIII Kal. Maias. For 
notes and details concerning the inscription see Comptes renclus de l' academie des inscriptions, 1896, p. 39. Cf. ch. X111.

Statura . . colore. . . corpore . . oculis . . fronie. . capillo: A considerable number of coins give us a general idea as to his personal appearance: Cohen I. pp. 229, $233,237-241,247-249$. In the Museo Capitolino there is a bust of Caligula which is deseribed as follows in the Catalogue of the Museo Capitolino published by the British School at Rome, volume I, page 109: "The eyes are small, the brow frowns. The face has a forbidding expression. The hair is in long, smooth locks, that lie elose to his head. . . . This is certainly antique, and without doubt Caligula, to whose coin portraits it has the strongest resemblance." A footnote adds: "Studniczka has reeently suggested that this is a portrait of Gaius Caesar, from its resemblance (especially in the shape of the forehead) to the portraits of his grandfather, Agrippa." Caligula would hardly relish this statement, in view of ch. XXIII, 1. See Appendix II.

\section{-LVI. 2-}

Palatinis ludis: These games are recorded in the Fasti Philocali and Silvii: CIL I². pp. 256-257. Cf. Dio 56. 46, 5; Josephus 19, 1, 11; and Tac. Ann. I. 73. It seems that an extra day was added to the usual number in the time of Caligula, and that he was murdered on that day. See Comm. Diurni, p. 308 in CIL I². Cf. Dio 59. 29.

\section{-LVII. 3-}

Fortumae Antiatinae: There are very few anthentie inscriptions which mention the Fortunae of Antium, the following being the only ones I have found: CIL X. $6555=$ Dessau 3697 from Velitrae: M. Ofasius | Firmus . . . Fortunis Antiatibus I d: d.; X. 6638c, 1. 28, the Fasti Antiates, where an aedituus Fortunarum is named; and a coin of Augustus, Cohen I. p. 138, n. $513=$ Eckhel V. p. 298: (Obverse) the busts of two women, presumably the Fortunae, and the inscription: Q. Rustius. Fortunae Antiat; (reverse) an altar, and the name Caesari Augusto. It is probably due to this dearth of authentic inscriptions that we have so many forged ones: CIL X. $957^{*}$ sqq. Cf. Hor., Odes, I. 35. 


\section{- LX-}

abolendam Caesarum memoriam: Though it is often a matter of conjecture as to whether a name has been erased from an inscription, there seem to be some clear cases of the erasure of Caligula's name: CIL III. $8742=$ Dessau 5984 V. $5722=$ Dessau 194 (ch. VII: Drusilla); X. 901 and 904; XI. 720 (ch. XXI), 3598 (ch. XXIV. 2); XII. 2331 (ch. XVII. 1); IGR I. 1057 (ch. XLIX. 2), and IV. 146. Caesonia's name, perhaps Caligula's also, appears to have been obliterated from an Arval inscription: CIL VI. 32347 (ch. XXV. 3), and that of Caligula's favourite sister, Drusilla, seems to have suffered like treatment in the following instance: IGR IV. 1098 (ch. XXIV. 2). It is not an easy matter to determine just why or when each erasure was made, but we do know that such acts have been resorted to even down to our own time as a mark of indignation against offenders. 


\section{APPENDIX}

It seems appropriate to include in an appendix the whole text of the fragment of the Fasti Ostienses referred to in connection with several passages of the text of Suetonius, e. g. chapters XIII, XIV, XVII, and XXIV, since at the same time it contains other information regarding events of Caligula's time:



PRAEF •

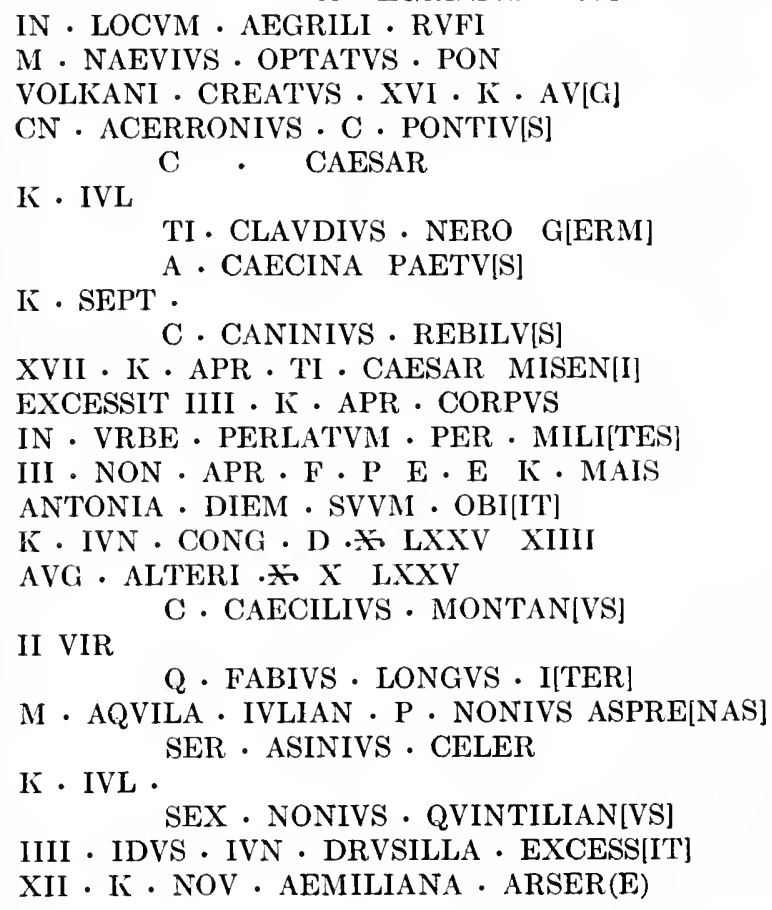


In addition to the particulars concerning the death and funeral of Tiberius (see the note on XIII), this inscription records several incidents of Caligula's principate of which Suetonius makes no mention: In lines 18-20 are found the names of the two consuls who succeeded Caligula and Claudius on September 1, 37 A. D. As was remarked before (ch. XVII. 1), this is information gained from no other source. The names are known in the consularfamilies, for Suetonius mentions Aulus Caecina Paetus as "consularis" in the reign of Titus (Tit. VI. 2; ef. also Iul. LXXV. 5); and speaks of Gaius Caninius Rebilus as the twenty-four hour consul of whom Julius Caesar made sport (Iul. IXXVI; Nero XV. 2). The date of Antonia's death (lines 24-25) is another fact heretofore unknown; and the exact date of Drusilla's death (liue 35) is a contribution, though it was known that she died about this time. The burning of the Aemiliana in $38 \mathrm{~A}$. D. (line 36 ) is a fact which we should have expected Suetonius to record. He does mention a fire in this section of Rome which occurred several years later during the reign of Claudius, according to his account (Claud. XVIII). There is little reason to surmise that he was confused about the date of it, especially since fires were so frequent and so destructive in ancient Rome. Dio refers to one in $38 \mathrm{~A}$. D. and tells of Caligula's aid to the sufferers (59.9), and it may he the one recorded in our inscription.

\section{APPENDIX II}

André Thevet, in his Cosmographic Universelle (Paris 1575) p. 815, writes as follows of a statue of Caligula and an inseription which he saw at Gallipoli: Aussi quand i'y estois, veis ie dans la maison d'vn Juif, vne image de Bronze, rapportant cest Empereur au naturel, qu'il auoit achetee d'vn Turc, pensant la faire fondre auec d'autres metaux pour ses affaires, comme ordinairement ils font: . . . Or à le bien aduiser, il monstroit qu'il estoit homme farouche \& sanguinaire, ayant vn visage refrogné, le menton court, les cheueux rares, \& les yeux foncez au visage. Je veis aussi vne pierre dans vn mur, contenant telle inscription: C. Caligula imp. August. pp., p. max. in sui nominis et Caesarum gloriam, huius urbis fundamenta iecit. Ann. ab urb. cond. VIIc. XCII. Non. Fehr. See chapters IX and XLIX. 2. 


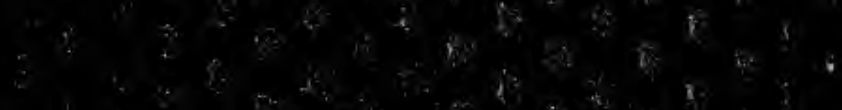

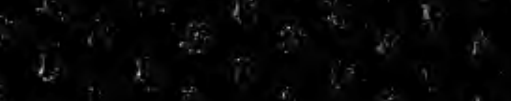



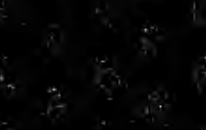





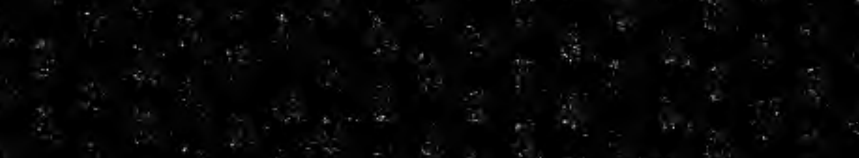

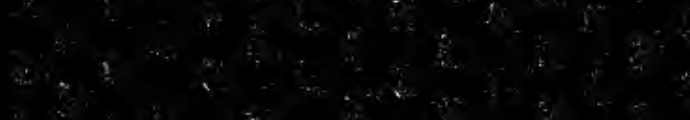

8

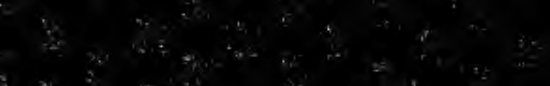

$x^{3}+$


4.

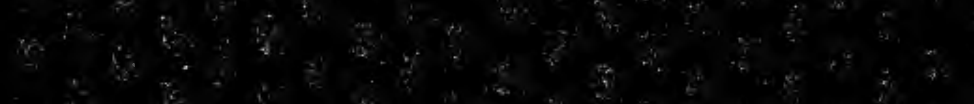

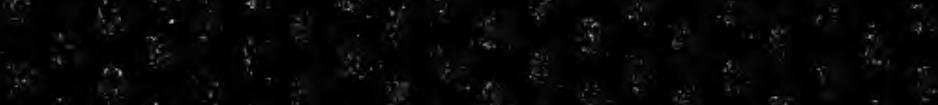

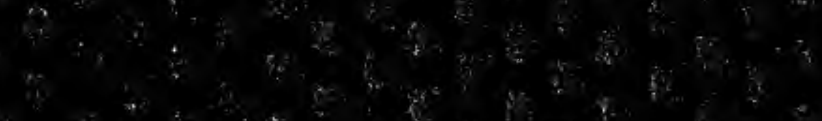

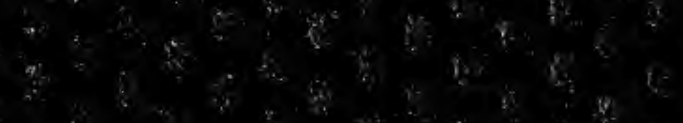




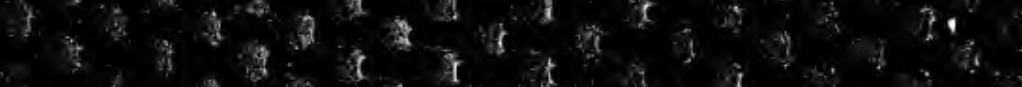

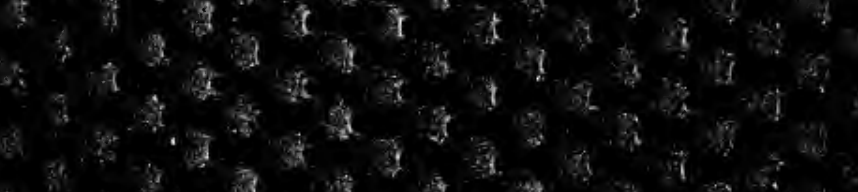

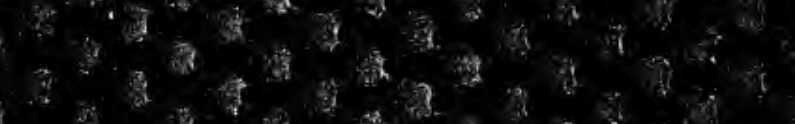

a

(3)

(i)

(a)

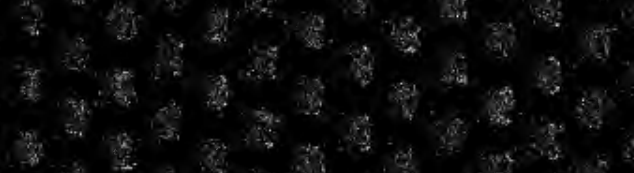

$\therefore \rightarrow \frac{4}{4}$



要

a.

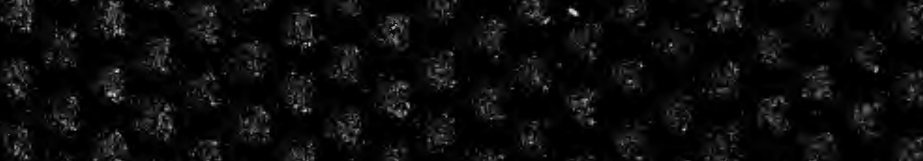

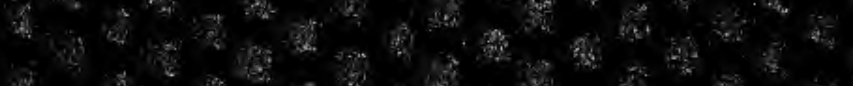

St.

\section{$x^{2} \times$}

-1


a d

a 